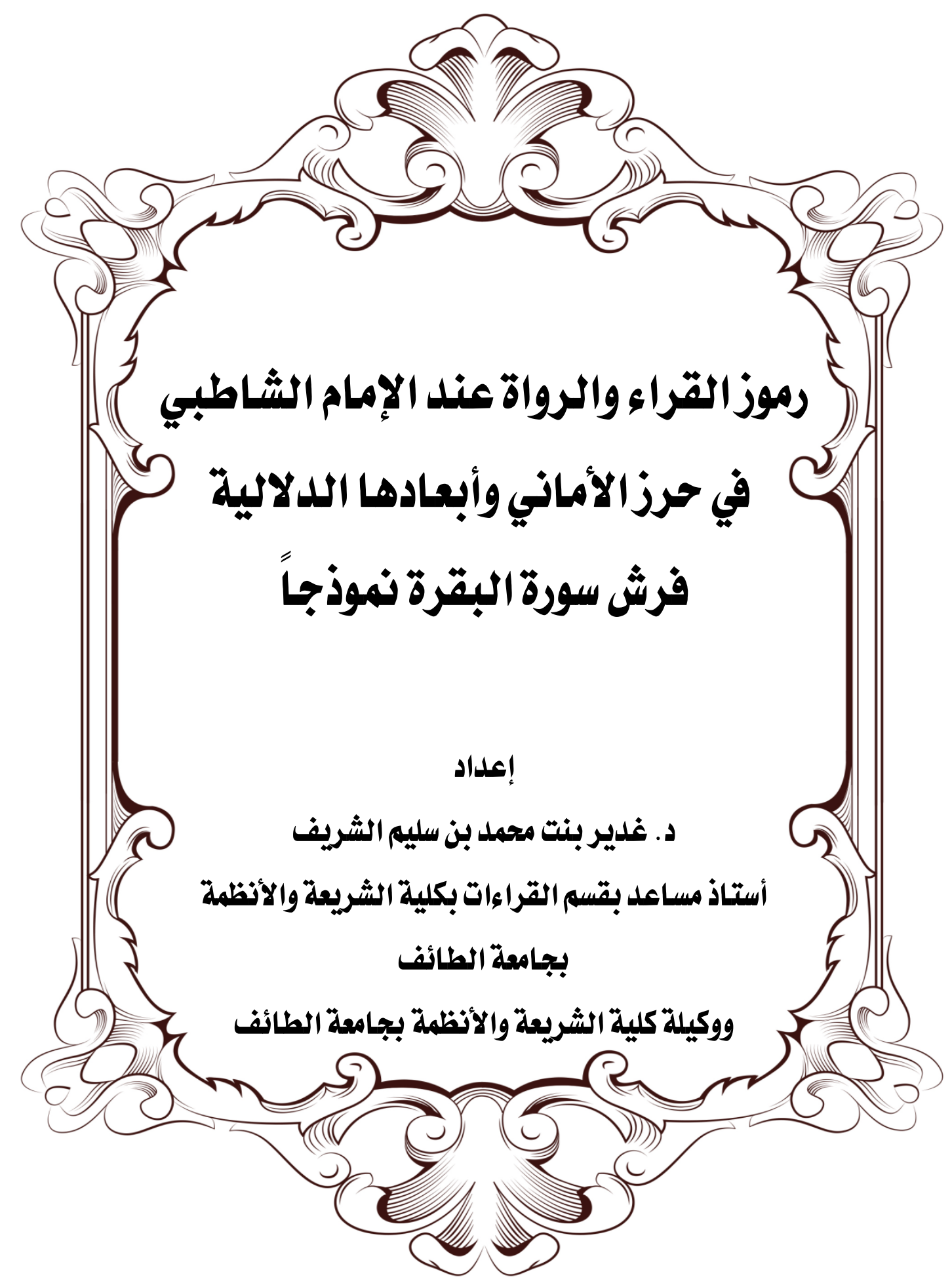


رموز القراء والرواة عند الإمام الثاطبي في حرز الأماني وأبعادها الدلالية فرش سورة البقرة نهوذجا

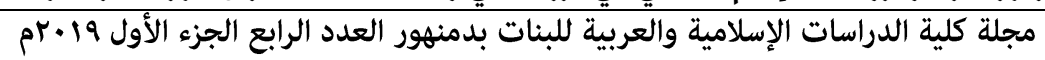


الحمد لله وحده، والصلاة والسلام على من لا نبي بعده، وبعد:

فهذا بحث بعنوان : رموز القراء والررواة عند الإمام الثاطبي في حز ول الأماني وأبعادها الدلالية.

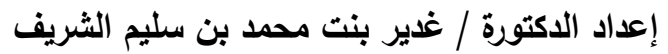

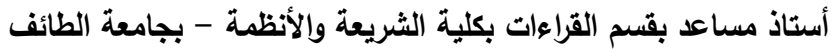

بينتُ فيه: أهمية هذا الموضوع؛ لتعلقه بمنظومة الثاطبية (حرز الأماني)، التي لم تكن وعاء للقراءات السبع فحسب، بل كانت غاية في البلاغة والبيان، قوية

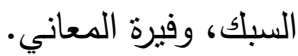

وقد جاءت هذه الدراسة في: مقدمة، وتمهيد، ومبحثين، وخاتمة.

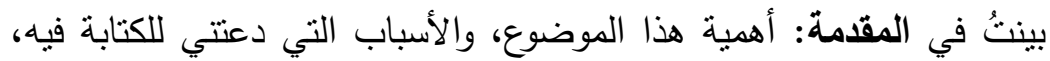
والخطة التي اتبعتها في تقسيمه، والمنهجية التي سلكتها في جمع مادته وكتابته، حيث اقتصرتُ على أبيات سورة البقرة كنموذج للدراسة. وذكرتُ في التمهيد: ترجمة مختصرة للإمام الثاطبي، كما عرّفتُ بالثاطبية، وشهرتها، ومكانتها عند القراء. وذكرت في المبحث الأول: منهج الإمام الثاطبي في نظم الثاطبية. وذكرت في المبحث الثاني: رموز القراء والرواة عند الإمام الثاطبي في حرز الامبن الأماني وأبعادها الد لالية، وجعلته في ثناثثة مطالب: * المطلب الأول: الإشارة في الرمز إلى تقوبة وجه ربما اعثُرض عليه وهيه. * المطلب الثاني: الإشارة إلى معنى من المعاني التي تتاسب سياق الكلمة المقروءة. * المطلب الثالث: الإشارة إلى توجيه القراءة. وأما الخاتمة: فقد ضمنتها أبرز النتائج، ومنها: 1- القيمة العلمية لمنظومة الثاطبية، واهتمام العلماء بها من حيث شرح أبياتها، وكثف أسرارها، وحل رموزها، وانكباب القراء عليها حفظاً وشرحاً ومدارسة.

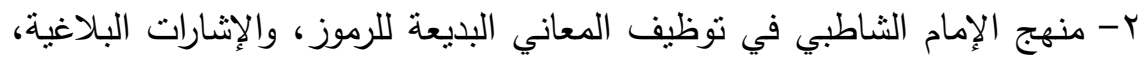
واللطائف التي اشتملت عليها: انتصاراً لقراءة، أو توجيهاً لها، أو مناسبةً لسياق.

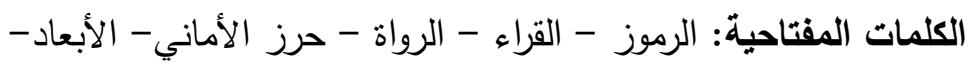
Email: Al-shareefanghadeer@hotmail.com 


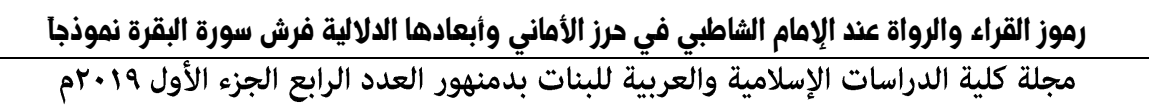

\section{Research Summary:}

Praise be to God alone, and peace and blessings be upon

those who have no prophet after him, and after:

This is a research entitled: The symbols of the readers and narrators in the Imam al-Shatby in the verse of the

Amani and its dimensions are semantic.

Prepared by Dr. Ghadeer bint Mohammed bin Salim Al

Sharif

Assistant Professor, Department of Readings, Faculty of

Sharia and Law, Taif University

The importance of this subject is important: it is related to the Shatibiyya system, which was not only a receptacle for the seven readings, but was an extremely eloquent and powerful statement.

This study came in: introduction, preface, two papers, and a conclusion.

I explained in the introduction: the importance of this subject, the reasons that led me to write it, the plan that I followed in its division, and the methodology I took in the collection and writing of it, where it was limited to the verses of Surat al-Baqarah as a model for study.

She said in the preface: A brief translation of the Imam Shati, as known as Sharbatia, and fame, and status among readers.

She said in the first topic: the approach of Imam Shati in the systems of Shatby.

In the second topic: the symbols of the readers and narrators in the Imam Shati in the verse of the aspirations and dimensions of the semantic, and made it in three demands:

* First requirement: The reference in the symbol to strengthen the face may object to it. 


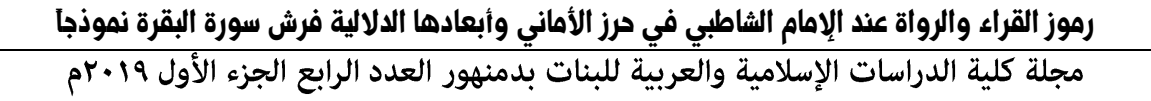

* The second requirement: to indicate the meaning of the meanings that fit the context of the read word.

* Requirement III: Reference to reading guidance.

As for the conclusion: it included the most prominent results, including:

1 - the scientific value of the system Shatbyip, and the interest of scientists in terms of explaining the verses, and reveal secrets, and solve the symbols, and the readers to focus on conservation and explanation and studied.

2 - the approach of Imam Shati in the use of wonderful meanings of symbols, and rhetorical signs, and the layers that included: a victory to read, or guidance, or appropriate context.

Researcher: Ghadir Bint Mohammed bin Salim AlSharif.

Keywords: Symbols - Readers - Narrators - Wish List -

Dimensions -

Email: Al-shareefanghadeer@hotmail.com 


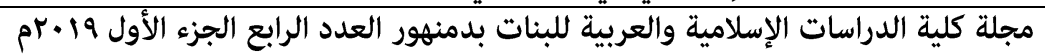

\section{المقدمة تبمات}

الحمد لله رب العالمين، وصلى الله وسلم على نبينا محمد، أثرف الأنبياء المرسلين، وعلى آله وصحبه الطيبين الطاهرين، ومن اقتفى أثرهم إلى يوم الدين. وبعد:

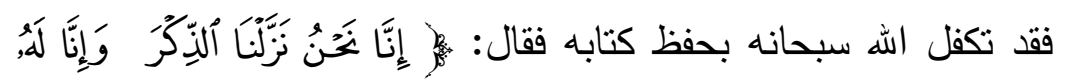

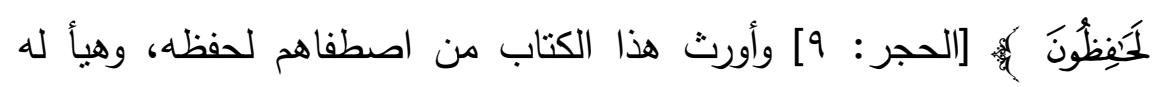
أسباب الحفظ، وكان من أزكى رجال الخلف الطيب طائفة من المصطفين الأخيار، اختارتهم العناية الإلهية للنهوض بهذه المأمورية تحملاً ورواية، ودراسةً ودراية، وتحربراً لوجوه القراءات، وتتقيحاً للطرق والروايات، وإتقاناً للأصول والفروع، وتجويداً للحروف، ومعرفةً بالأداء والوقوف، فكانوا في زمانهم وبعده الحصن الحصين لكتاب الله(1)، فألفوا المؤلفات نظماً ونثراً خدمة لكتاب الله عز وجل.

ومن أهم المنظومات في القراءات منظومة: (حرز الأماني ووجه

التهاني) التي نظمها الإمام الثاطبي (r) -رحمه الله- وضمّنها كتاب (التيسير) لأبي عمرو الداني(ّ)، وهي من أهم الآثار التي تركها الإمام الثاطبي، وقد لاقت قبولاً منقطع النظير، وطافت بالبلاد، وحفظها طلاب هذا الفن، إلى هذا اليوم، ولم بحظ كتاب في القراءات بما حظيت به هذه المنظومة، فكثز شراحها، وتعددت مختصراتها، وظلات موضع اهتمام العلماء قديماً وحديثاً،

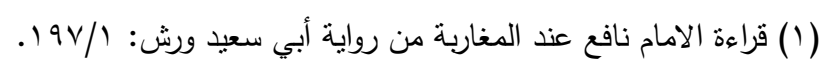

$$
\begin{aligned}
& \text { (Y) ستأتي ترجمته مفصلة لاحقاً. }
\end{aligned}
$$

(r) هو عثمان بن سعيد بن عثمان بن سعيد بن عمر الأموي، مولاهم القرطبي، قرأ على أبي الفتح

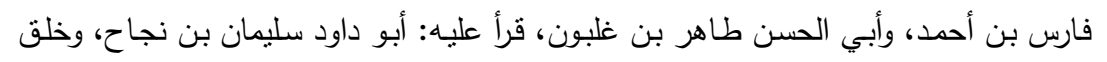

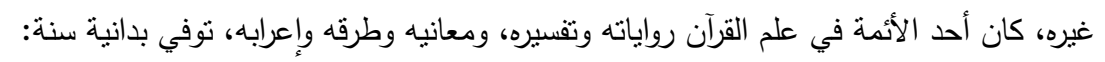

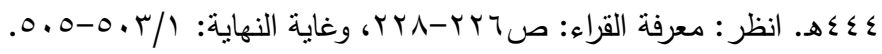




\section{رموز القراء والرواة عند الإهام الثاطبي في حرز الأهاني وأبعادها الدلالية فرش سورة البقرة نهوذجا}

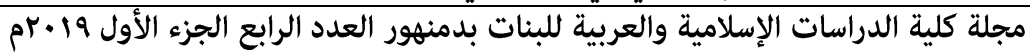
ولا تزال هذه المنظومة هي العمدة لمن أراد إتقان القراءات السبع حتى اليوم، فهي بـحق كما قال العلامة ابن الجزري|(1): " من وقف على قصبيدته علم مقدار ما آتاه الله في ذللك، خصوصاً اللامية عجز البلغاء من بعده معارضتها، فإنه لا يعرف مقدارها إلا من نظم على منوالها، أو قابل بينها وبين ما نظم على طريقتها، ولقد رُزق هذا الكتاب من الثهرة والقبول مالا أعلمه لكتاب غيره في هذا الفن، بل أكاد أن أقول ولا في غير هذا الفن، فإنني لا أحسب بلداً من بلاد الإسلام يخلو منه، بل لا أظن أن بيت طالب علم يخلو من نسخة (r)" (r)

ويقول الإمام الذهبي() في كتابه (معرفة القراء الكبار): " ولقد سارت

الركبان بقصيدتيه حرز الأماني وعقيلة أتراب القصائد، اللتين في القراءات والرسم، وحفظهما خلق لا يحصون، وخضع لها فحول الثعراء، وكبار البلغاء، وحذاق القراء، فلقد أبدع وأوجز، وسهل الصعب، لذا تلقاها العلماء في سائر

الأعصار والأمصار بالقبول الحسن وعنوا بها أعظم عناية "(£).

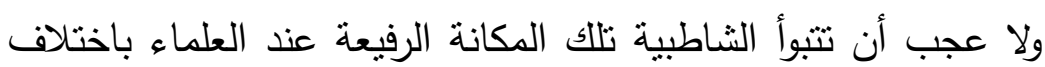
تخصصاتهم، فلم تكن وعاء للقراءات السبع فحسب، بل كانت غاية في البلاغة

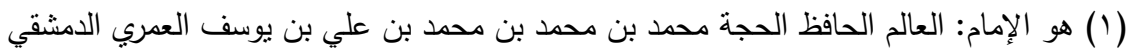

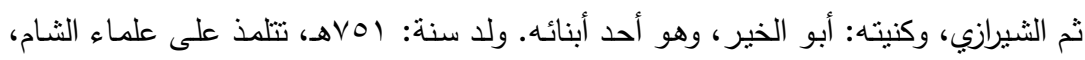

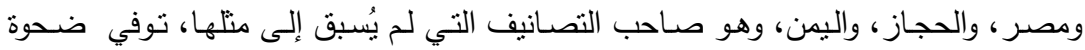

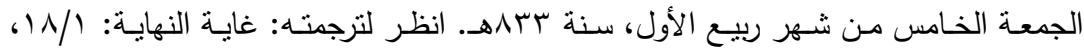

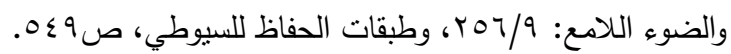

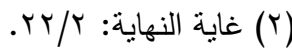

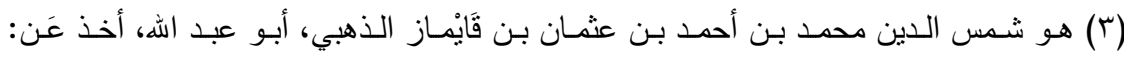

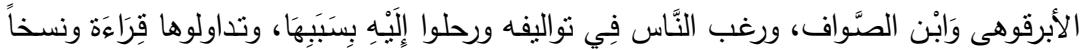

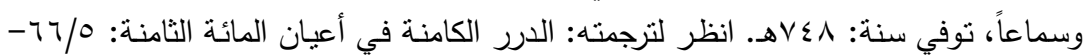




\section{رموز القراء والرواة عند الإهام الثاطبي في حرز الأماني وأبعادها الدالية فرش سورة البقرة نهوذجا}

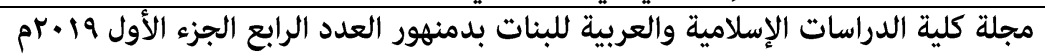

والبيان، قوية السبك، وفيرة المعاني، حيث أبدع الإمام الثاطبي في استعمال الرمز ودمجه في الكلام، فاستعمل الرموز عوضاً عن أسماء القراء أو الرواة، ولم يكن همه الرمز فقط، بل وظَّف هذه الرموز للالالة على معانٍ بديعة، وتحرّى هذه المعاني، التي لولا الرموز لما حصلنا عليها. ومن هنا جاء

$$
\text { اختياري لهذا الموضوع. }
$$

أهمية الموضوع وسبب اختياره:

ا - تعلقه بالقراءات القرآنية التي هي من أشرف العلوم لاتصالها المباشر

بالقرآن الكريم.

r- القيمة العلمية لمنظومة الثاطبية، والتي مازالت تحتوي على الكثير من

$$
\text { الدرر التي لم يتم اكتشافها. }
$$

"- عدم التعرض لرموز الثاطبية دن حيث صلتها بالمعاني في بحث مستقل،

يجمع ماورد من إشارات في ثتايا شروح الثاطبية.

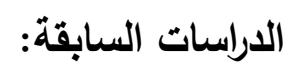

من خلال بحثي في هذا الموضوع لم أجد من تعرض لدلالات الرموز

$$
\text { لاى الإمام الثاطبي في حرز الأماني في بحث مسثقل. }
$$


قمت بتقسيم هذا البحث إلى : مقدمة، وتمهيد، ومبحثين، وخاتمة.

$$
\text { أولاً: المقدمةة: }
$$

بيّنتُ فيها: أهمية الموضوع وأسباب اختياره، والدراسات السابقة، وخطة

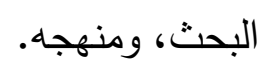

ثانتيًا: التمهريد: وفيه:

أولاً: تزجمة الإمام الشاطبي ترجمة مختصرة.

ثانيًا: التعربف بالثاطبية، وشهرتها، ومكانتها عند القراء.

ثالثًا: المبحث الأول: منهج الإمام الثاطبي في نظم الثاطبية.

رلبعاً: المبحث الثاني: رموز القراء والرواة عند الإمام الثاطبي في حرز

الأماني وأبعادها الدلالية، وفيه ثثلاثة مطالب:

* المطلب الأول: الإشارة في الرمز إلى تقوية وجه ربما اعتُرض عليه.

* المطلب الثاني: الإشارة إلى معنى من المعاني التي تناسب سياق الكلمة

$$
\text { المقروعة. }
$$

* المطلب الثالث:الإشارة إلى توجيه القراءة. خامساً: الخاتمة: وفيها أهم النتائج.

سادساً: الفهارس: وفيها:-

ا- فهرس الآيات القرآنية.

r- فهرس الأعلام.

r- فهرس المصادر والمراجع •

ع- فهرس الموضوعات. 
نهجت في كتابة هذا البحث المنهج الاستقرائيّ الوصفيّ، واقتصرت على الى أبيات فرش سورة البقرة كنموذج لهذه الدراسة.

$$
\text { إجراءات البحث: }
$$

1- إذا نقلت من مصدر بالنص جعلت المنقول بين حاصرتين هكذا " " ثم أث

أحلت على المصدر في الهامش، وإذا كان النقل بالمعنى أو بتصرف قلت فئن

$$
\text { انظر • مع ذكر الجزء والصفحة. }
$$

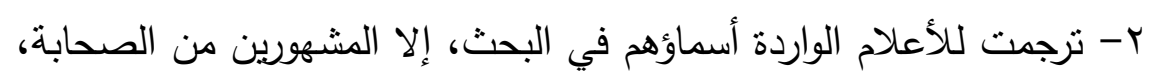

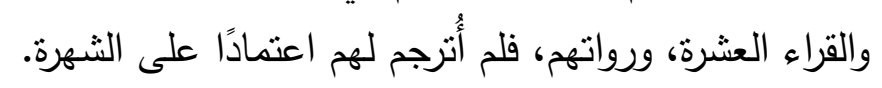

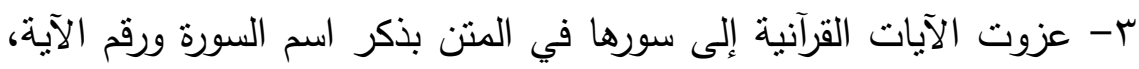

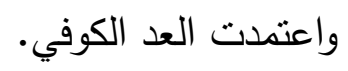

$$
\text { ع - كتبت الآيات بالرسم العثماني. }
$$

0- وضعت فهارس فنية على النحو الموضح في الخطة.

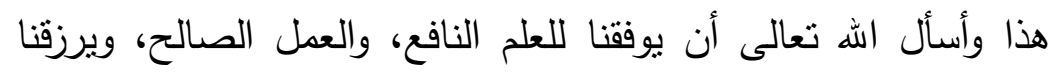

السداد في الأقوال والأفعال، وصلى الله وسلم على نبيه محمد وعلى آله لهاله وصحبه وسلم.

الباحثة: غدير بنت محمد الثريف 
هو أبو القاسم، أو أبو محمد، القاسم بن فِيرُة بن خلف بن أحمد

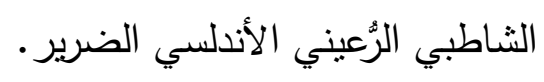

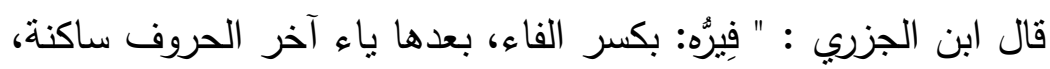

ثم راء مشددة مضمومة بعدها هاء، ومعناه بلغة عجم الأندلس: الحديد "(1).

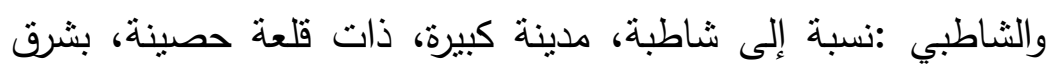

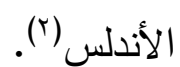

مولده:ولد الثاطبي في آخر سنة ثمان وثلاثثن وخمسمائة بشاطبة.

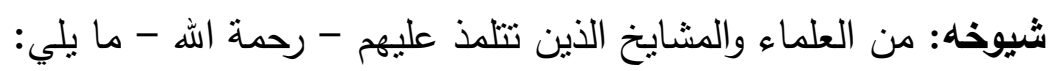

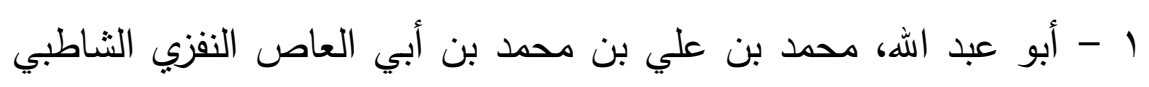

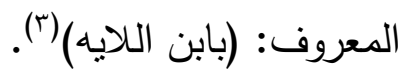

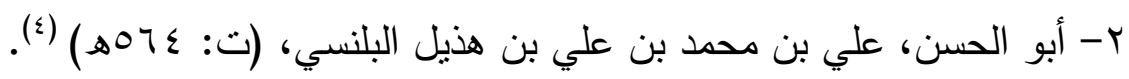
ب- أبو عبد الله، محمد بن يوسف بن بن مفرج الإثبيلي، (ت: بل . . 7هـ) (0).

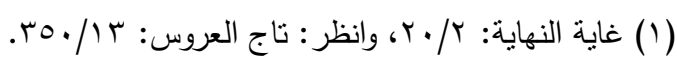

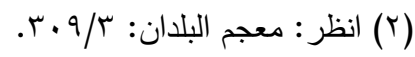

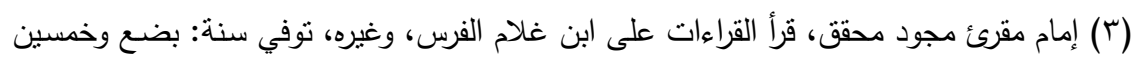

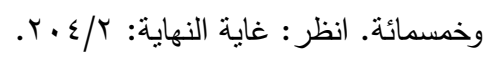

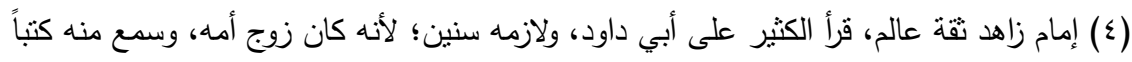

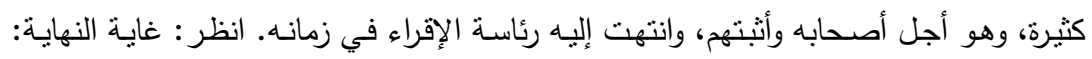

$$
.0 \mathrm{~V} \varepsilon-0 \mathrm{VT} / \mathrm{T}
$$

(0) مقرئ محقق، قرأ على شريح، وأحمد بن محمد بن حرب المسيلي، وغيرهم، وكان مقرئاً فاضلاً

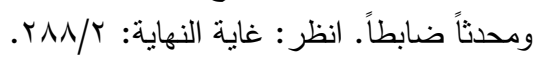




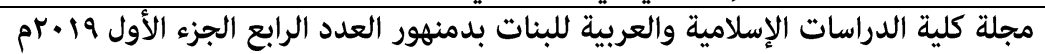

تلاميذه:

من المعلوم أن الثاطبي - رحمة الله - جُعِل شيخاً للمدرسة الفاضلية

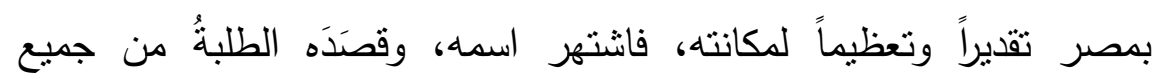

الأقطار ، فمن تتلمذ عليه - رحمة الله - واستفاد من علمه ما يلي :

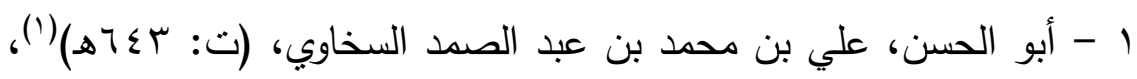

وهو من أجل أصحاب الثاطبي.

r- أبو عبد الله، محمد بن عمر بن بوسف الأنصاري القرطبي المالكي،

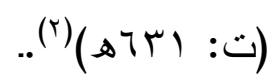

ب- أبو الحسن، علي بن محمد بن موسى بن أحمد الجمال بن أبي بكر

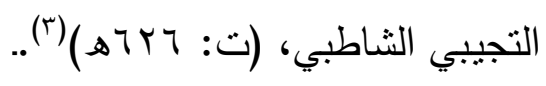

(1) شيخ مشايخ الإقراء بدمشق، روى عن: أبي طاهر بن عوف، والبوصبري، وغيرهم، كان إمامًا

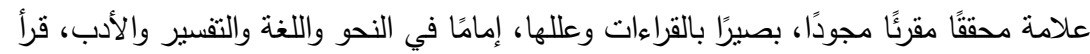

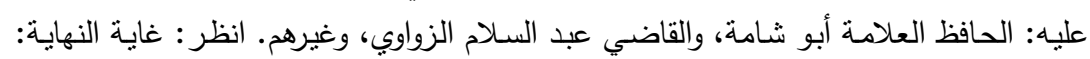

$$
.0 V 1-071 / 1
$$

(Y) إمام عالم فقيه مفسر نحوي زاهد مقرئ، روى عن: أبي محمد بن عبيد اله الحجري، ويحيى بن إهن

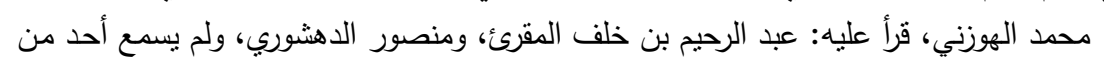

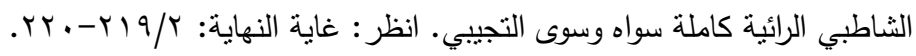

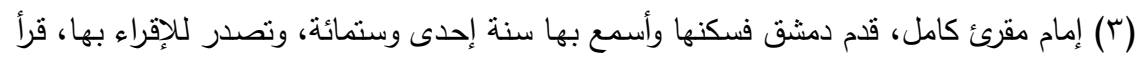

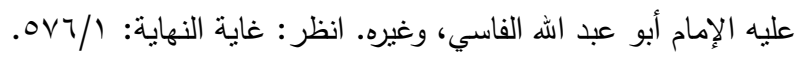


يكفي في إدراك عظيم مكانه ومكانته في علوم الرواية وغيرها: أننا نجده

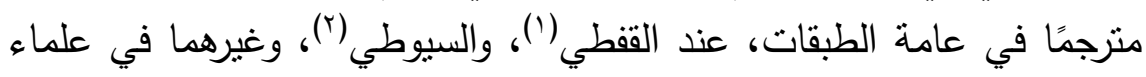

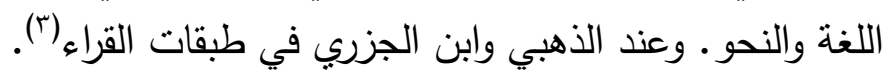
وعند الداوودي() وغيره في طبقات المفسرين.

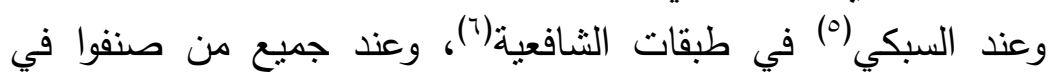

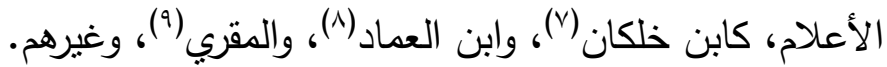

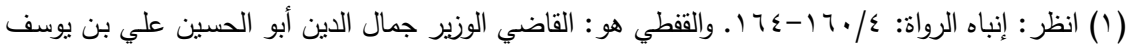

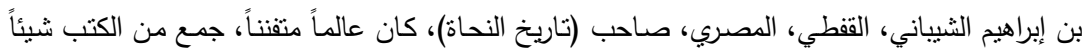

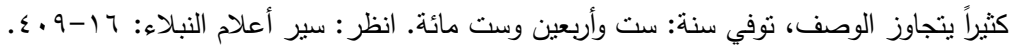

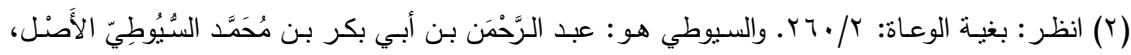

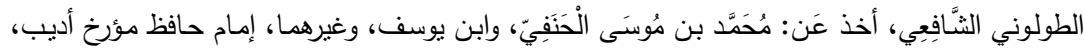

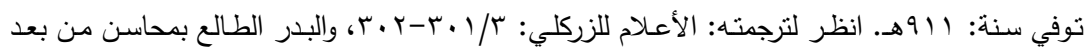

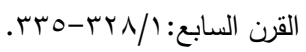

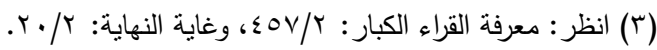

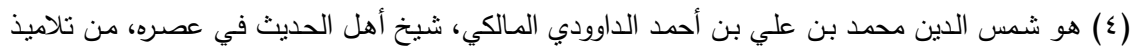

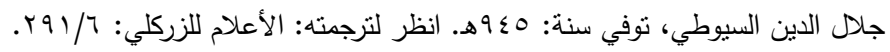

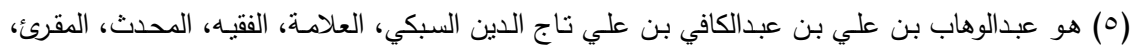

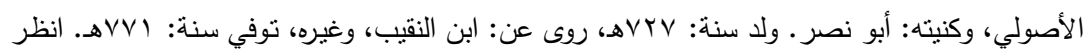

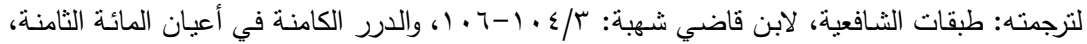

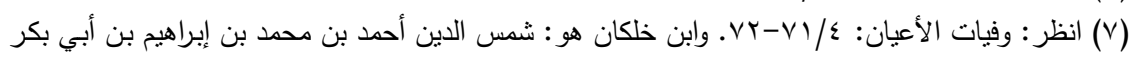

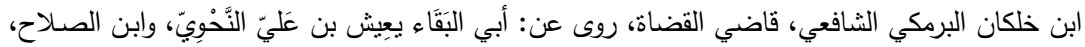

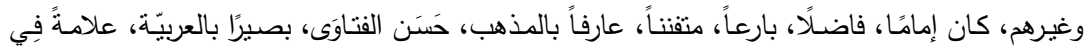

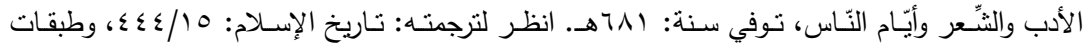

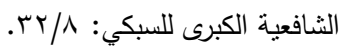

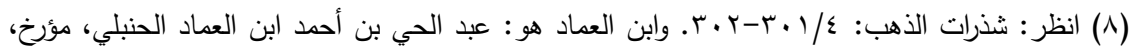

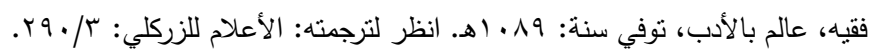

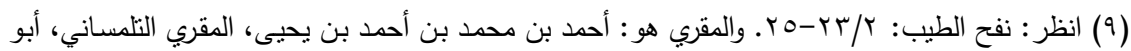

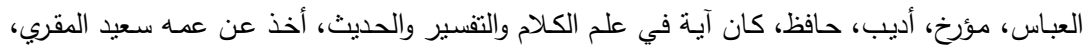

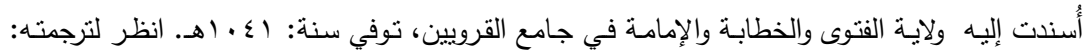

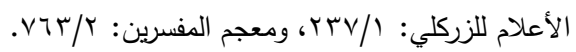




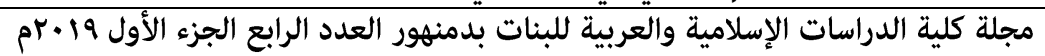

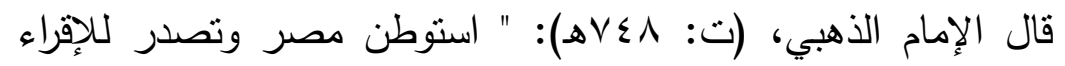

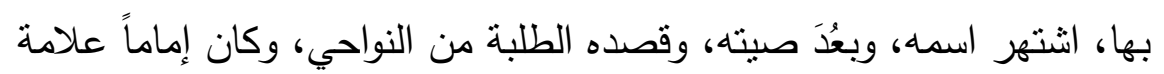
ذكياً، كثير الفنون، منقطع القرين، رأساً في القراءات، حافظاً للحديث، بصيراً بالعربية، واسع العلم... وكان متجنباً فضول القول، ولا يتكلم في سائر أوقاته إلا بما تدعو إليه الضرورة، ولا يجلس للإقراء إلا على طهارة في هيئة حسنة، وخضوع واستكانة، ويمنع جلساءه مِن الخوض إلا في العلم والقرآن، وكان يعتلّ لآل العِلّة الثديدة فلا بشتكي، ولا يتأوه " ( ). وسوف نرى من خلال عرض مؤلفاته القيمة -رحمه الله- مزيدًا من التتوبه بشخصيته، والاعتراف له من أهل العلم بالنبوغ البعبد المدى، والبراعة المنقطعة النظير، في مجال النظم التعليمي، والإحاطة والحذق في الفن. وفيما يلي أهم آثاره العلمية، وما قام عليها من نشاط (r).

( )- القصيدة اللامية، المسمّاة بـ(حرز الأماني ووجه التهاني)(r).

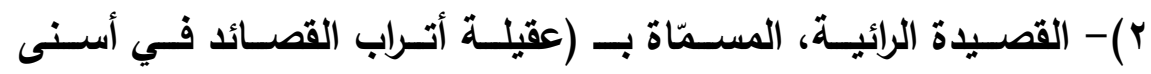
المقاصد)(ء): نظم فيها مسائل كتاب (المقتع) لأبي عمرو الداني (ت:

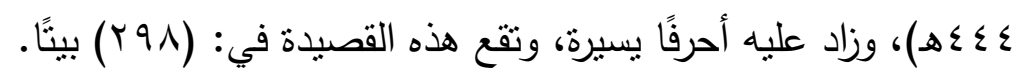
وقد حظيت هذه المنظومة بشروح كثيرة منها ما يلي: أ- (الوسيلة إلى كثف العقيلة)، للإمام علم الدين السخاوي (ت: بـ آهـ).

(1) (1) معرفة القراء الكبار ، صكا آس.

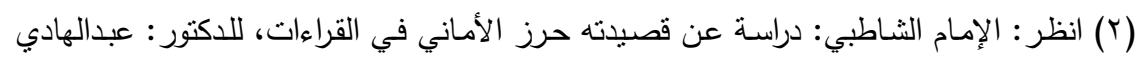

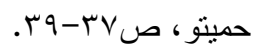

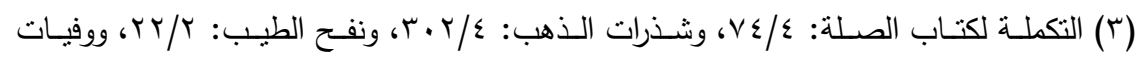
الأعيان:

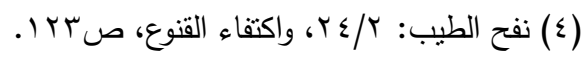




\section{رموز القراء والرواة عند الإهام الثاطبي في حرز الأهاني وأبعادها الدلالية فرش سورة البقرة نهوذجا}

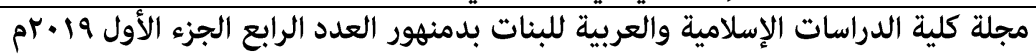
ب)- (جميلـة أربـاب المراصـد في شـرح عقيلـة أتـراب القصـائد)(')، للإمـام

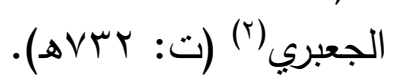

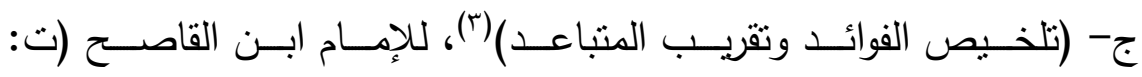
( $)^{(\varepsilon)}(\Delta \cdot)$ د- (الهبات السنية العلية على أبيات الثاطبية الرائية)(0)، للملا علي قارئ (†)( 1 (ت)

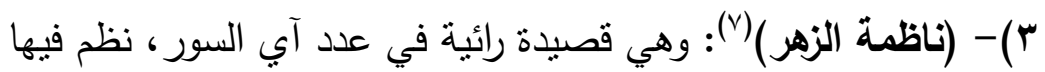
تأليف: الفضل بن شاذان الرازي (ت: في حدود • جr هـ)(^)، وقد حظيت هذه القصيدة بعدة شروح منها:

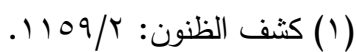

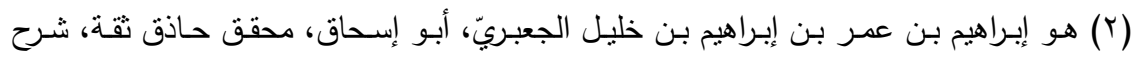

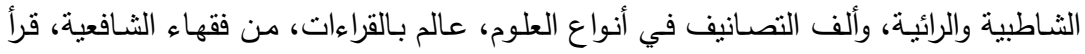

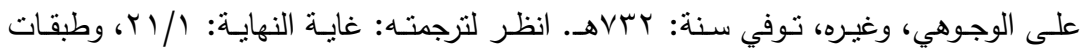

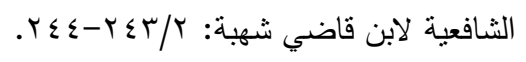

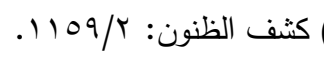

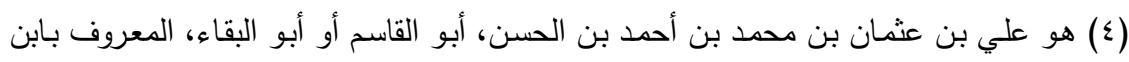

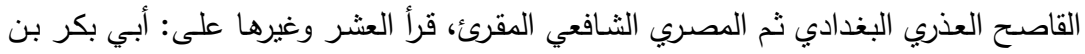

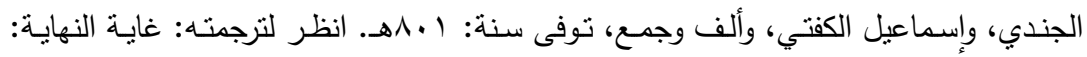

$$
.000 / 1
$$

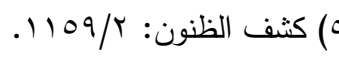

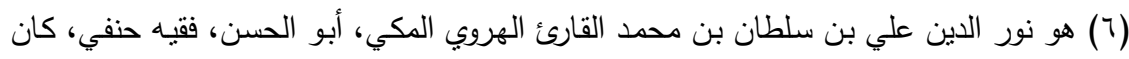

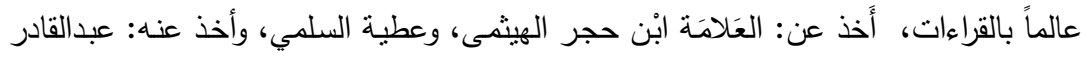

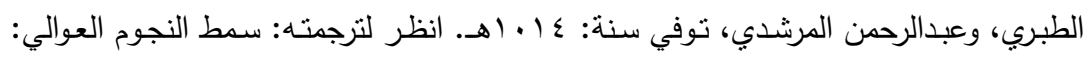

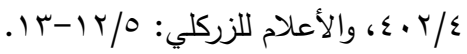

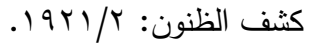

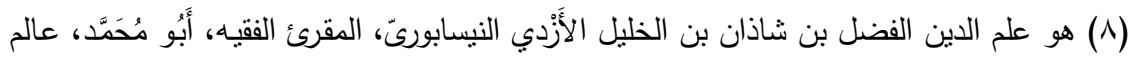

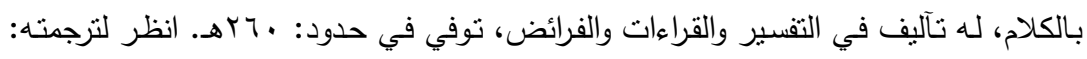

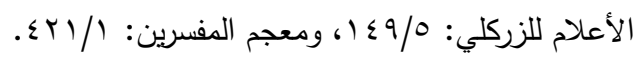




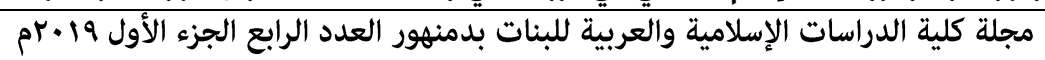

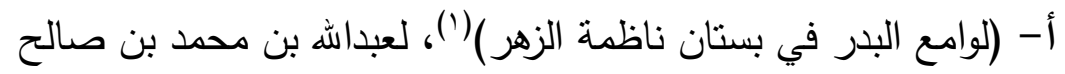

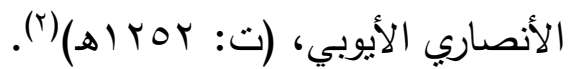

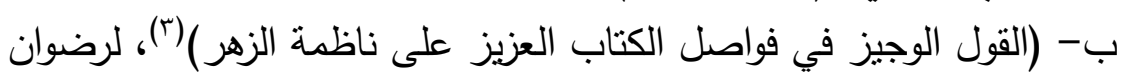
بن محمد المخلاتي (ت: 11 ابا هـ) (ء). وفاته: توفي -رحمه الله- بمصر يوم الأحد بعد صلاة العصر الثامن والعشرين من جمادى الآخرة، سنة: تسعين وخمسمائة للهجرة، ودفن بالقرافة(ه). ثاتياً: التعريف بالشاطبية وشهرتها، ومكانتها عند القراء:

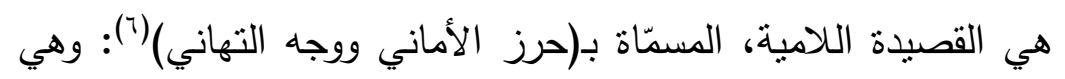
منظومة لامية على بحر (الطويل) مكونة من س IV بيثًا، ذكر الثاطبي أنه نظم أولها بالأندلس، إلى قوله: ناله

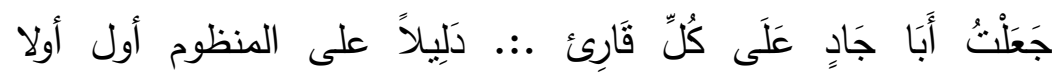
وأَكْملها بالمدرسة الفاضلية بالقاهرة، وقد ضمن الثاطبي كتاب (التيسير) للذاني في هذه المنظومة تسهيلًا لحفظه، وزاد عليه بعض الخلافات، وهي ما

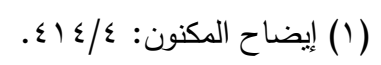

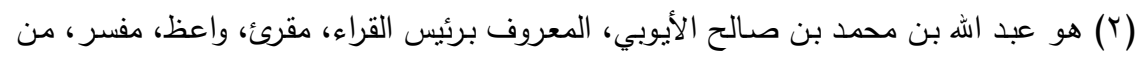

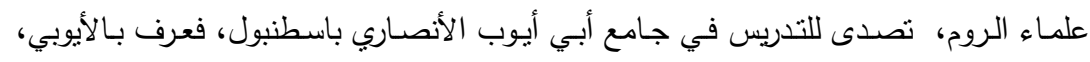

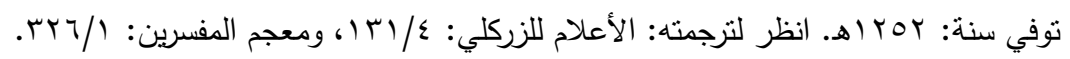

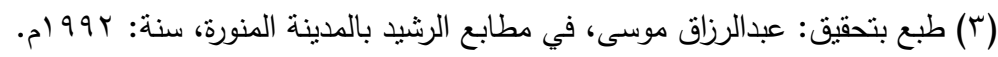

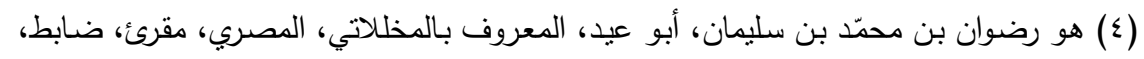

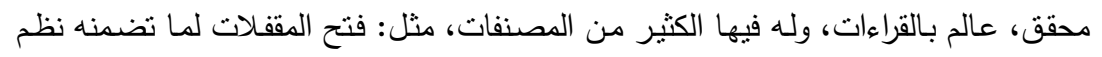

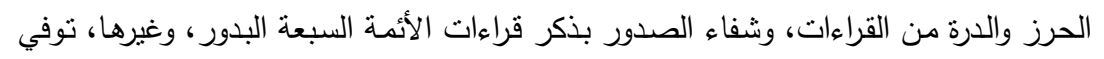

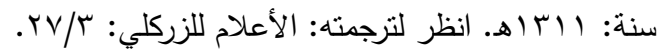

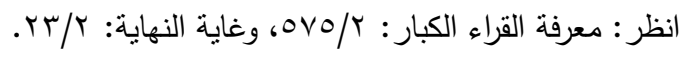

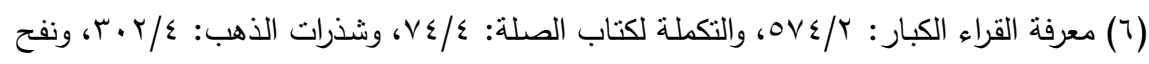

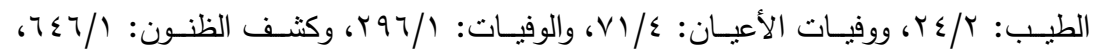

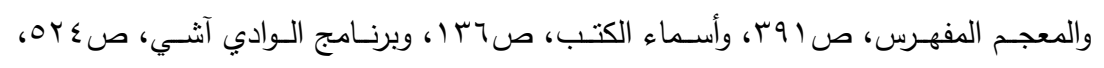

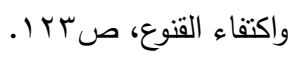




\section{رموز القراء والرواة عند الإمام الشاطبي في درز الأماني وأبعادها الدالية فرش سورة البقرة نهوذجا}

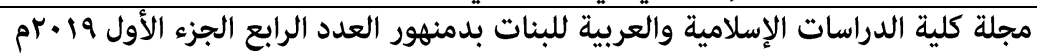

عرف فيما بعد بزبادات القصبد، أي ما زادته الثاطبية على التيسير، يقول الثاطبي رحمه الهة:

\section{فأجنــت بعـون الله منــه مـؤملا}

وفي يسرها التيسير رمت اختصاره

فلفت حيـاء وجههـا أن تفضـلا
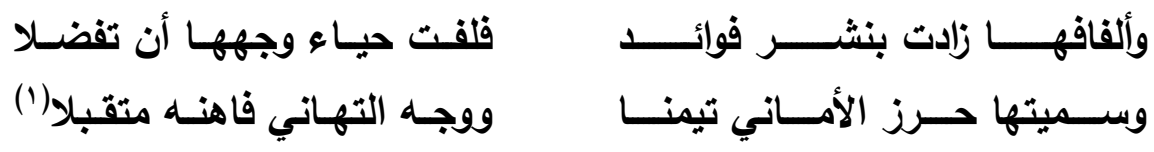

وقد عني العلماء من أئمة القراء وأهل الفن بشرح هذه القصبدة المباركة، أو التعليق عليها، أو اختصارها، حتى تجاوزت نلاك الجهود مائة مؤلف مابين شرح وتعليق واختصار • غير أنه لم يطبع من شروحها باللغة العربية -حسب علمي- إلا نحو خمسة عشر شرحًا، وهي:

ا- (فـتح الوصـيد فـي شـرح القصـبد) للإمـام: علـم الـدين السـخاوي (ت:

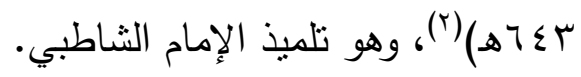

r- (إبـراز المعـاني مـن شـرح حـرز الأمـاني) لأبـي شـامة المقدسـي (ت

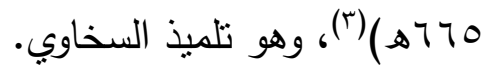

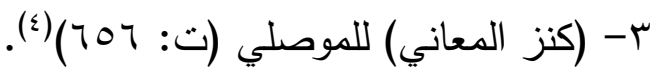

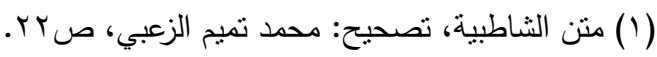

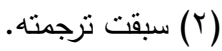

(r) هو شهاب الدين عبد الرحمن بن إسماعيل بن إبراهيم بن عثمان، المقدسي الأصل، الدمثقي

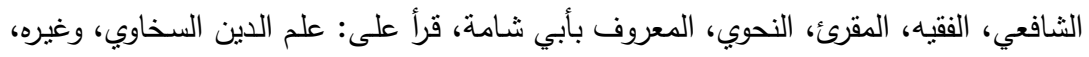

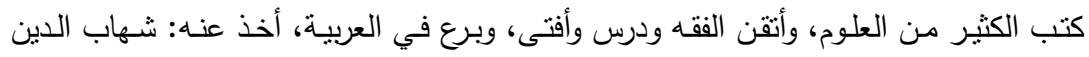
حسين الكفري، وغيره، توفي سـنة:

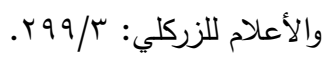

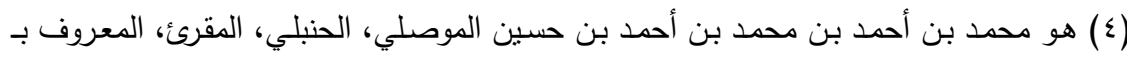

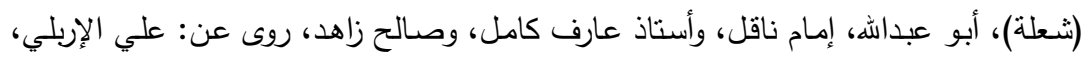

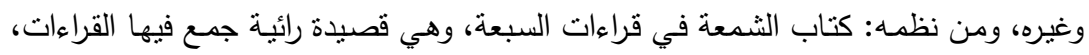

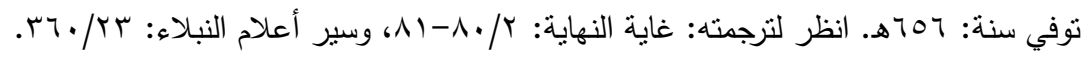




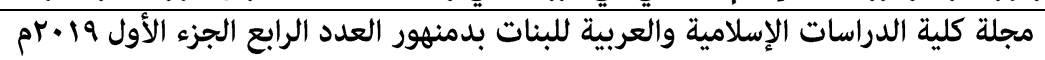

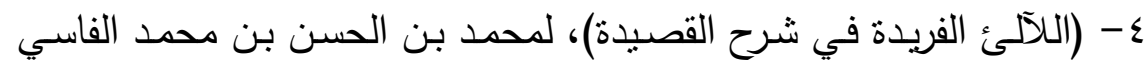

$$
\text { (') (ت: (1) }
$$

0- جزء من: (العقد النضيد) للسمين الحلبي (r)(ت:

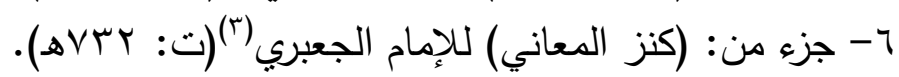

- (سراج القارئ المبتدي وتذكار المقرى المنتهي) للإمسام ابن القاصح (ء)(ت:

$$
\cdot(\Delta \wedge \cdot 1
$$

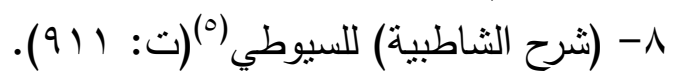

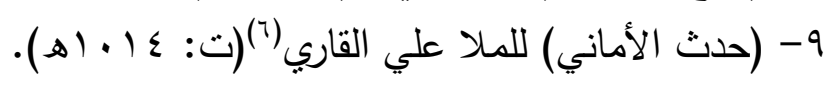

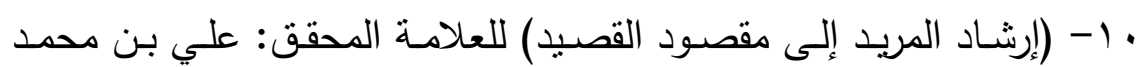

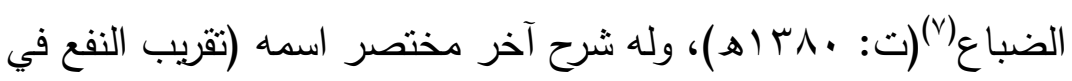

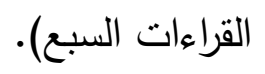

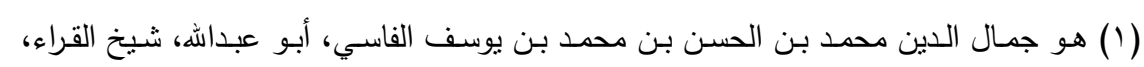

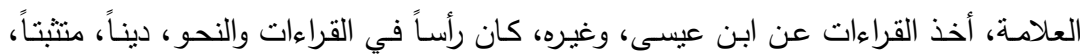

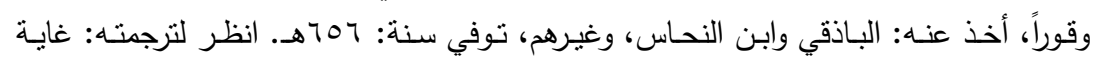

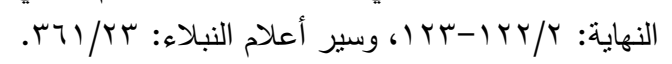

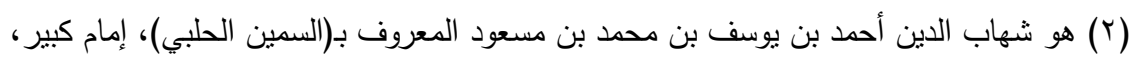

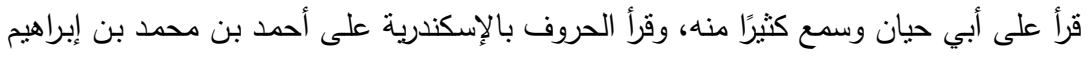

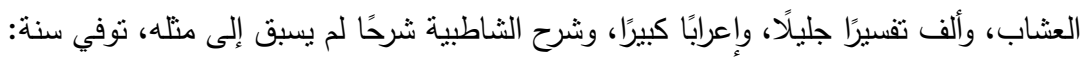

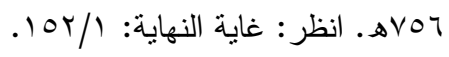

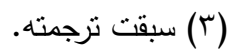

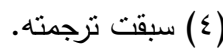
(1) (1) سبقت نرجمته.

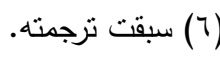

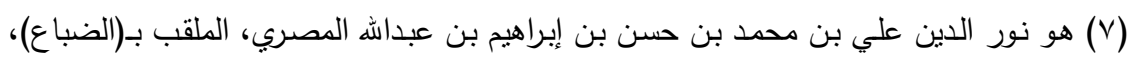

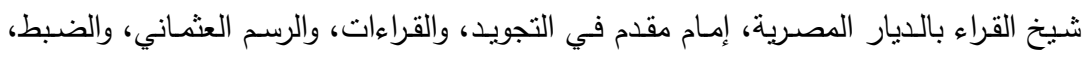

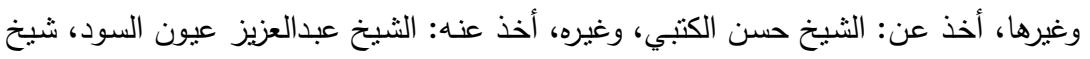

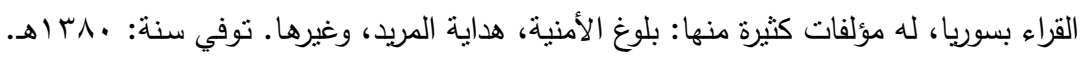

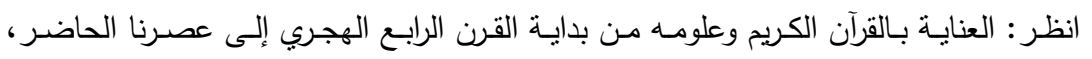




\section{رموز القراء والرواة عند الإهام الشاطبي في حرز الأهاني وأبعادها الدلالية فرش سورة البقرة نهوذجا}

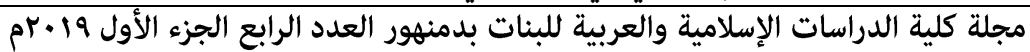
1 ا- (الـوافي في شـرح الثـاطبية في القـراءات السـبع) للثـيخ: عبـدالفتاح

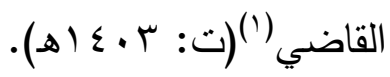

r ا - (تقريب المعاني في شرح حرز الأماني في القراءات السبع) لسبد لاشين

$$
\text { أبو الفرح، وخالا محمد الحافظ. }
$$

ب ا - (المزهر في شرح الثاطبية والدرة) للجنة من الأساتذة بعمان الأردن. ء ا- (النفحات الإلهية في شرح منن الثاطبية) للثيخ محمد عبدالدايم خميس.

$$
\text { } 10
$$

وهناك شروح أخرى متعددة حققت في رسائل علمبة في الجامعات، في

$$
\begin{aligned}
& \text { مرحلتي الماجستير والدكتوراه، ولم تطبع بعد(؟). } \\
& \text { مكانتها عند القراء: }
\end{aligned}
$$

إن مما يبين مكانة هذه المنظومة عند القراء هو ثناء العلماء عليها، قال الذهبي (ت: V^^): " وقد سـارت الركبـان بقصسيدتيه، حرز الأمـاني وعقيلـة

(1) هو شيخ مشايخنا عبد الفتاح بن عبد الغني بن محمد القاضي، عالم مبرز في القراءات

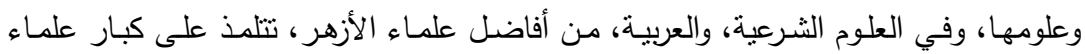

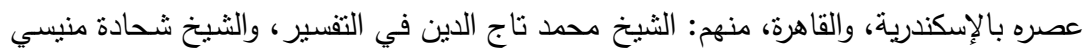

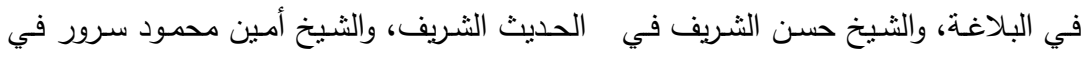
التوحيد، وغيرهم، عُين رئيسًا لقسم القراءات بكلية اللغة العربية بالأزهر، وشيخًا للمعهد الأزهري

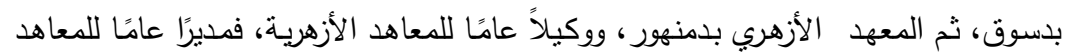

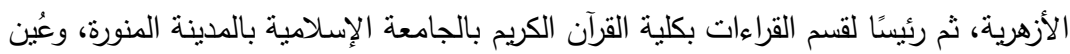

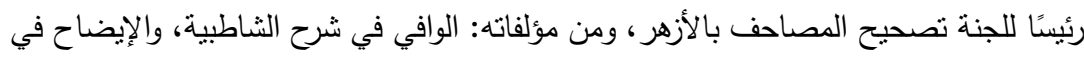

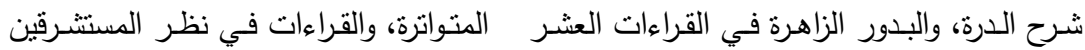

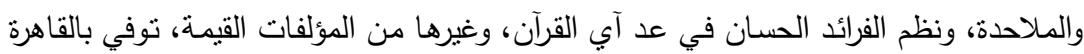

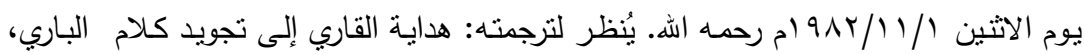

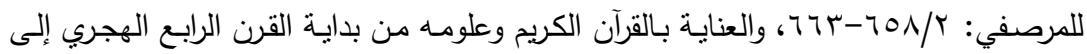

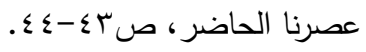

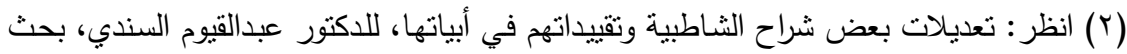

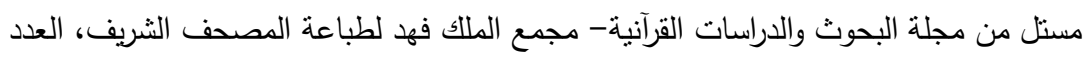




\section{رموز القراء والرواة عند الإهام الثاطبي في حرز الأماني وأبعادها الدالية فرش سورة البقرة نهوذجا}

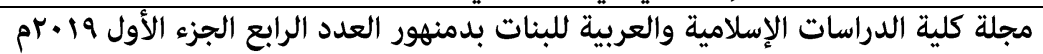

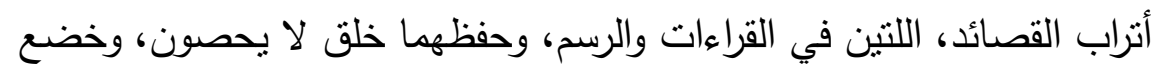
لهما فحول الثعراء، وكبار البلغاء، وحذاق القراء "(1).

وقال الإمام ابن الجزري: " ومن وقف على قصيدتيه علم مقدار ما آتاه

الهه في ذلك، خصوصًا اللامبة التي عجز البلغاء مـن بعده عن معارضتها، فإنه لا يعرف مقدارها إلا من نظم على منوالها أو قابل بينها، وبين ما نظم على طريقها، ولقد رزق هذا الكتاب من الثهرة والقبول ما لا أعلمه لكتاب غيره في هذا الفن، بل أكاد أن أقول: ولا في غير هذا الفن فإنني لا أحسب أن بلداً

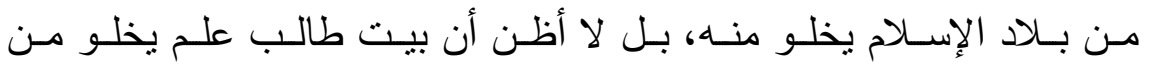

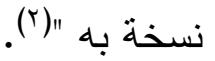
وقال ابن خلكان: "ولقد أبدع فيها كل الإبداع، وهي عمدة قراء هذا الزمان في نقلهم، فقل من يشتخل بالقراءات إلا وبقدم حفظها ومعرفتها، وهي مشـتملة على رمـوز عجيبـة، واشتـارات خفيـة لطيفـة، ومـا أظنـة سـبق إلـى

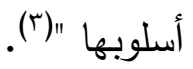


رهوز القراء والرواة عند الإهام الثاطبي في درز الأهاني وأبعادها الدلالية فرش سورة البقرة نهوذجا

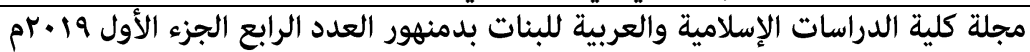

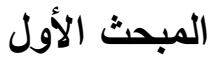

\section{منهج الإمام الثاطبي في نظم الثاطبية:}

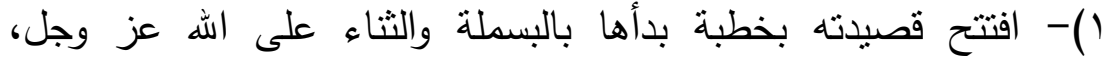

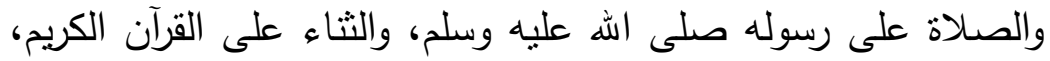
وفضل حامل القرآن الكريم، ثم ذكر القراء السبعة ورواتهم ورموزهم. r) - ابتدأ بأصول القراء، وهي: القواعد والأحكام الكلية الدطردة، التي يجري

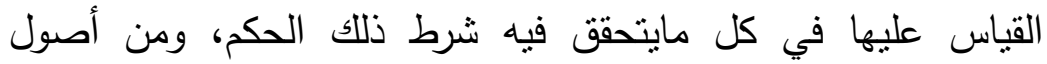
القراءات: ميم الجمع، الإدغام الصغير والكبير، الإمالات، وغيرها.

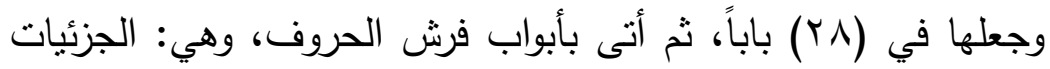

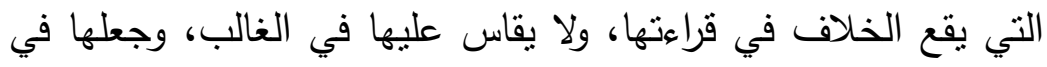

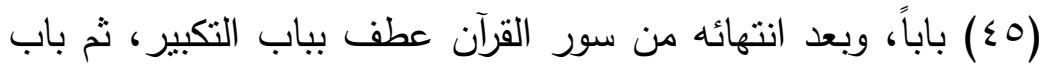

$$
\text { مخارج الحروف وصفاتها. }
$$

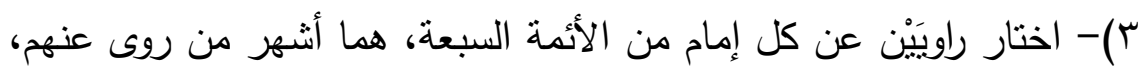
- -ولو بواسطة- ولفضلهم علماً وعملاً وزهداً في الانيا.

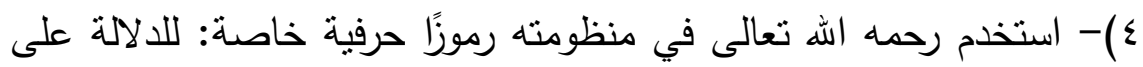

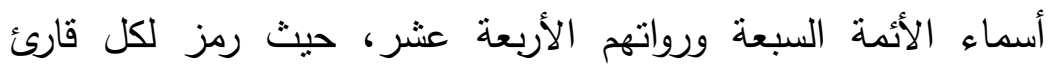
بحرف، ولكل مجموعة من القراء برمز، فجعل الحرف الأنة الأول للقارئ

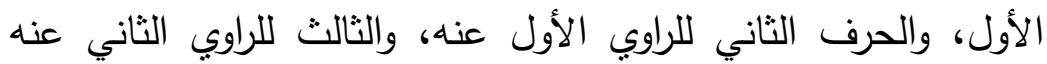
وهكذا.

وهذه الحروف هي: أبج، دهز، حطي، كلم، نصع، فضق، رست. ف

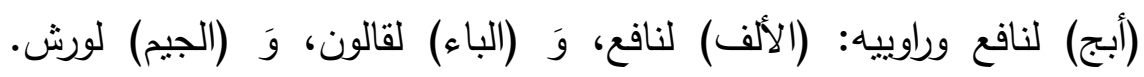
(ودهز) لابن كثير وراوييه: (الدال) لابن كثير، وَ (الهاء) للبزي، وَ (الزابي)

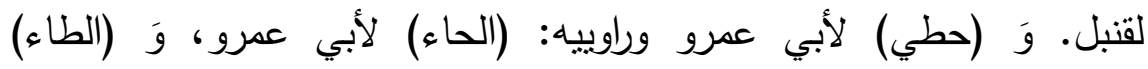

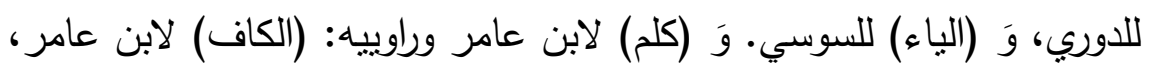

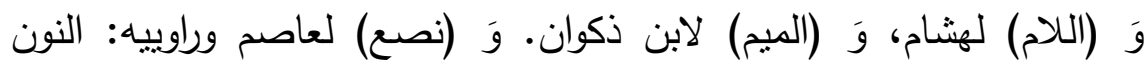




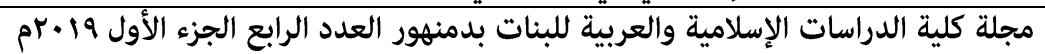

(لعاصم)، وَ (الصاد) لشعبة، وَ (العين) لحفص. وَ (فضق) لحمزة وراوبيه: (الفاء) لحمزة، وَ (الضاد) لخلف، وَ (القاف) لخلاد. وَ (رست) للكسائي وراوبيه: (الراء) للكسائي، وَ (السين) لأبي الحارث، وَ (التاء) لحفص الدوري. ثم بقي من حروف (أبي جاد) ستة أحرف وهي: الثاء، والخاء، والذال، والظاء، والغين، والثين، ويجمع هذه الحروف كلمتا (ثخذ ظغش)، فجعل

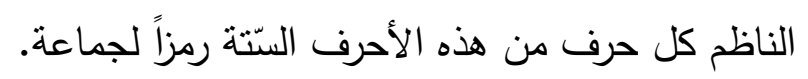

ف (الثاء) رمز للكوفيين الثناثة: عاصم وحمزة والكسائيّ، إذا اتفقوا في هذه

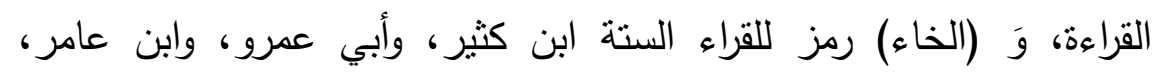
وعاصم، وحمزة، الكسائي، وَ (الذال) لابن عامر والكوفيين الثلاثة، وَ (الظاء) لابن كثير والكوفيين، وَ (الغين) لأبي عمرو البصري والكوفيين، وَ (الثين) لحمزة والكسائي، وإلى هنا تتتهي الرموز الحرفية التي يكون الرمز فيها حرفاً، ويرمز بـه لقارئ أو أكثز كما سبق.

وأما الرموز الكلمية -وهي التي يكون الرمز فيها كلمة يرمز بها لأكثز من قارئ- : فكلمة (صحبة) رمز لحمزة والكسائي وشعبة، وكلمة (صحاب) ردز لحمزة والكسائي وحفص، وكلمة (عم) ردز لنافع وابن عامر ، يأتي اسماً

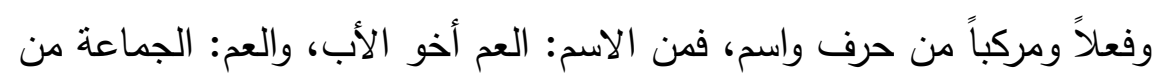
الناس والمحترم منهم، والفعل من العموم، ومن المركب أصله (عن ما) فأدغم وحذف ألف الاستقهام.

وكلمة (سما) رمز لنافع وابن كثير وأبي عمرو، ومعناه: علا وارتفع، وقد

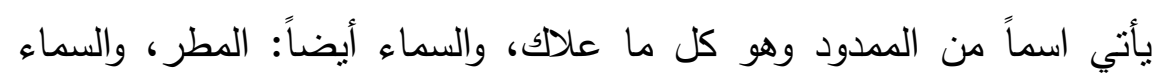
واحد السموات، يذكّر وبؤنّّث.

وكلمة (حق) رمز لابن كثير وأبي عمرو، ومعناه: خلاف الباطل. وكلمة (نفر) رمز لابن كثير وأبي عمرو وابن عامر • وكلمة (حرمي) رمز لنافع وابن كثير، وأصله نسبة إلى الحرمين الثربفين فخفف كما خفف غيره من 


\section{رموز القراء والرواة عند الإهام الثاطبي في حرز الأهاني وأبعادها الدلالية فرش سورة البقرة نهوذجا}

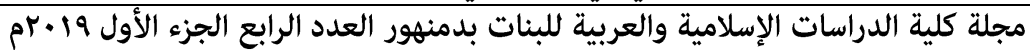
المكي والمدني ونحوه، وأجري مجرى المنقوص. وكلمة (حصن) رمز لنافع والكوفيين.

وفي الجملة فكل هذه الكلمات دالة على الثناء بالكفاية والصحبة والاصطحاب والصفا والفتوة والرواية والثبات والحماية والسمو، ونحو ذللك، وقد استعمل هذه الرموز بحسب ما يناسب من المعاني. 0)- يذكر الناظم أولاً الكلمة القرآنية المختلف فيها ثم يذكر قراء هذه الكلمة برموزهم المذكورة سابقاً، واضعاً هذه الرموز في أوائل كلمات متضدنة لمعان جليلة، فإذا انقضت هذه الرموز أتى بالواو فاصلة بين الكلمة التي ذكر حكمها والكلمة التي سبيّين حكمها بعد. وهذا إذا ذكر القراء برموزهم فإنه يلتزم ذكر الكلمة القرآنية أولاً ثم يذكر قراءها، أما إذا ذكر القراء بصربح أسمائهم فلا يلتزم هذا الترتيب، فقد يبدأ بذكر الكلمة القرآنية ويثني بذكر قرائها كقوله في سورة النحل: (يدعون عاصم)، وقد بذكر القارئ أولاً ثم يذكر الكلمة، كقوله في سورة البقرة: (وحمزة أسرى...) إلخ. 7) قد يترك الواو الفاصلة وذلك في أحرف من القرآن إذا اتصلت لا يلتبس أمرها، ولا يرتاب الناظر فيها. P - قد يكتفي بلفظ القرآن أي: بالتلفظ بالكلمة القرآنية ولا بقيدها بقصر أو مد، أو غيبة أو خطاب أو نحو ذللك، وذلك إذا كان اللفظ دالًّ على المقصود كاشفاً عنه، ولم يحتج للتقيد، كقوله في سورة العنكبوت: (ويدعون نجم حافظ)، فلم يقيد (يدعون) بالغيب؛ لاتضاح المعنى وظهوره من اللفظ. ^)- إذا قبد القراءة بقيد وكان هذا القيد ضدّا لقيد القراءة الأخرى: فإنه يكتفي بذكر قبد القراءة الأولى ويترك ذكر قيد القراءة الأخرى؛ اختصاراً، فإن أحد الضدين يدل على الآخر، مثلى: المد والقصر، والإثبات والحذف، فإذا ذكر الإثبات فضده الحذف وبالعكس، والفتح فضدّه الإمالة وبالعكس، والإدغام فضده الإظهار وبالعكس، والهمز فضده نركه وبالعكس، وهكذا يقال في بقية الأضداد المذكورة، ما عدا الجزم فإن ضده الرفع، ولكنه 


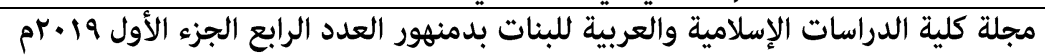

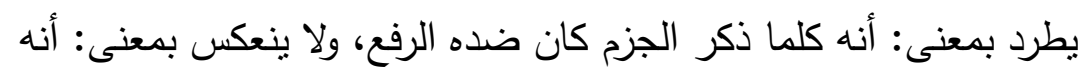
إذا ذكر الرفع لم يكن ضده الجزم، بل يكون ضده النصب. 9)- إذا ذكر التحريك غير مقيد بحركة فالمراد به الفتح، كقوله: (معاً قدر حرك من صحاب). وضده حينئذ الإسكان، وإذا ذكر الإسكان كان ضده الفتح، وبؤخذ من هذا: أن الإسكان ضد التحريك سواء كان التحريك مطلقاً أم مقيداً، فإذا كان ضد السكون حركة غير الفتح فإنه يقيدها، كقوله: (وأرنا وأرني ساكنا الكسر).

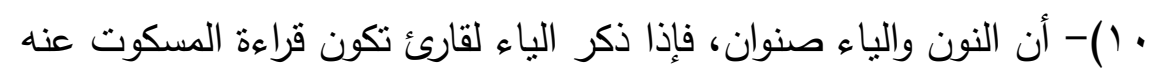
بالنون، وإذا ذكر النون لقارئ تكون قراءة المسكوت عنه بالياء. والقتح والكسر ضدان، فإذا ذكر الفتح لقارئ تكون قراءة غيره بالكسر، واذا ذكر الكسر لقارئ تكون قراءة غيره بالفتح. والنصب والخفض ضدان، فإذا ذكر النصب لقارئ فقراءة غيره بالخفض، وإذا ذكر الخفض لقارئ فقراءة غيره بالنصب، فالمؤاخاة بين ما ذكر مؤاخاة تضاد.

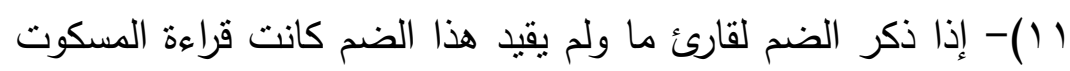
عنه بالفتح، وإذا ذكر الرفع لقارئ ما ولم يقيده كانت قراءة المسكوت عنه بالنصب، أما إذا قبد الضم بكونه ضم الإسكان فنكون قراءة الغير بالإسكان، وكذللك إذا قبده بكونه ضم الكسر فتكون قراءة الغير بالكسر، واذا قيد الرفع بكونه رفع الجزم كانت قراءة الغير بالجزم، وإذا قيده بكونه رفع الخفض كانت قراءة الغير بالخفض.

r ( ) - قد بذكر الكلمات التي فيها الرفع والتذكير والغيب: بذكر هذه الكلمات مطلقة، فيعلم من إطلاقه لها أنها هي المرادة لا أضدادها، مثاله: (وأربع أولا صحاب)، يعني: بالرفع. (ويجبي خليط)، يعني: بالتذكير، (وبل يؤثرون حز)، بعني: بالغيب.

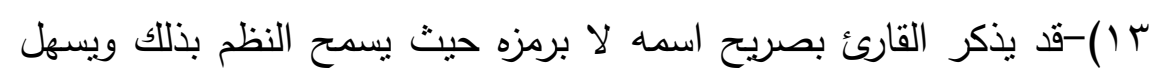
عليه. 
10)- زادت هذه القصيدة على كتاب (التيسير) بفوائد ليست فيه، كزيادة

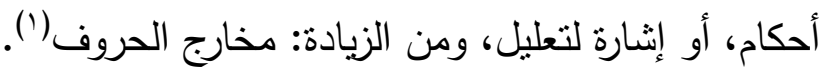

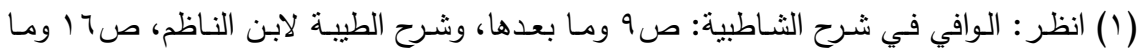

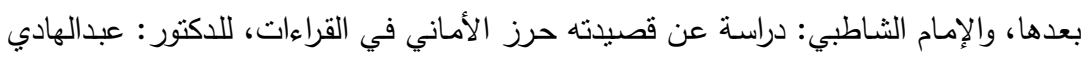
حميتو، صسمر وما بعدها. 


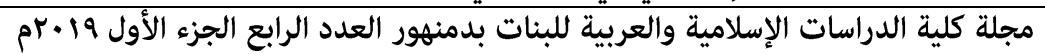

$$
\text { المبحث الثاني }
$$

رموز القراء والرواة عند الإمام الثاطبي في حز الأماني وأبعادها

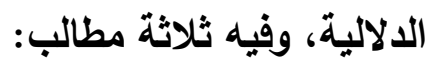

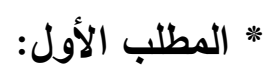

الإثارة في الرمز إلى تقوية وجه ريما اعتُرض عليه، وفيه فروع:

$$
\text { - الفرع الأول: }
$$

قول الإمام الشاطبي رحمه الله:

وها هو بعد الواو والفا ولامها ... وها هي أسكن راضياً بارداً حلا

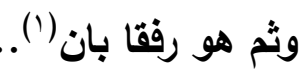

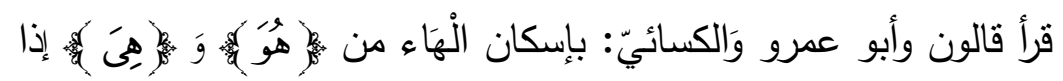

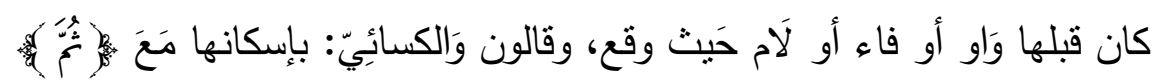

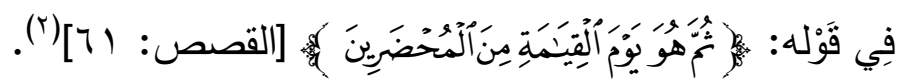

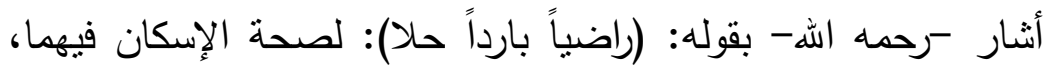

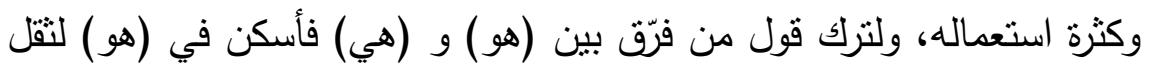
الضم، ورآه أحسن من الإسكان في (هي)؛ لكون الكسر أخف، فئن فالإسكان مرضيّ فيهما.

ووصفه بأنه بارد حلو بمنزلة ماء بارد حلو يَروي من قرأ به، كما يروي

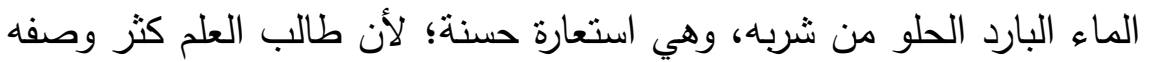
بالظمأ إلى العلم.

ومعنى قوله: (رفقا بان) أب: أسكنه في حال كونك ذا رفق، أي:

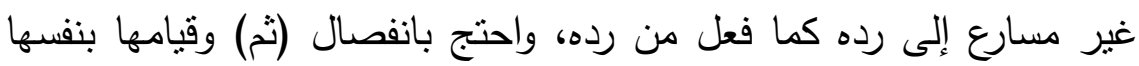

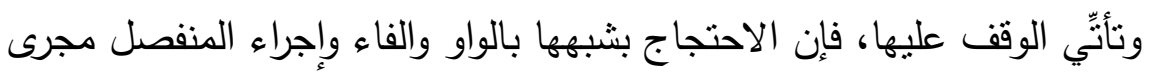

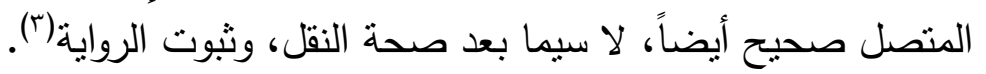


رهوز القراء والرواة عند الإهام الشاطبي في درز الأماني وأبعادها الدلالية فرش سورة البقرة نهوذجا

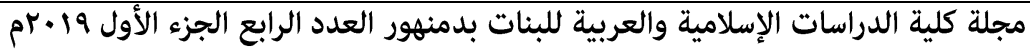

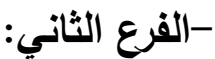
قول الإمام الشاطبي رحمه الله:

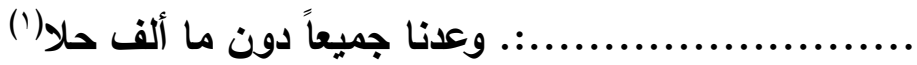

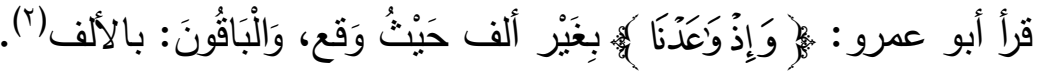
وأشار بقوله (حلا) إلى اختيار جماعة من الحذاق لهذه القراءة؛ لموافقة اللفظ

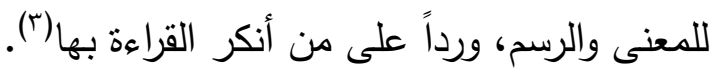
-الفرع الثالث: قول الإمام الشاطبي رحمه الله:

وحمزة أسرى في أسارى وضمهم .:. تفادوهمو والمد إذ الق نفلاء)

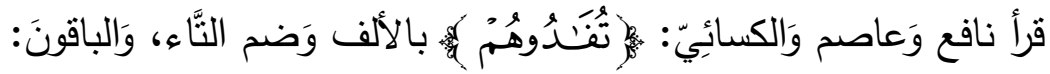
بغيْر ألف وَفتَح الثَّاء (ن). وأثار -رحمه الله- بقوله: (راق نفلا) إلى تقوبة هذه القراءة، وتصحيح معناها، فمعنى (راق): أعجب أو: صفا، يقال: راق الشراب أي: صفا. ومعنى (نفل): زاد وأعطى نفلاً، والنفل: الغنيمة، يثني على هذه القراءة بذلك؛ لأن بعض العلماء اختاروا القراءة الأخرى عليها(ج). -الفرع الرابع: قول الإمام الشاطبي رحمه الله:

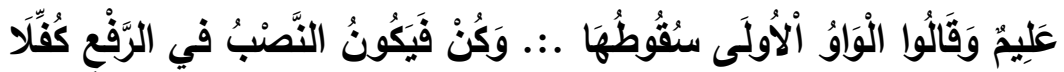

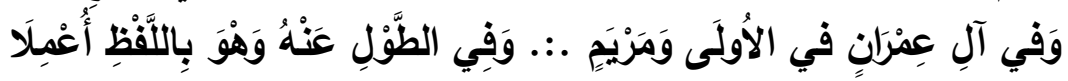

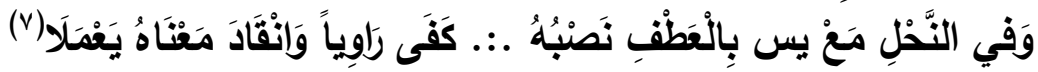

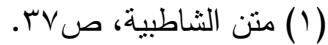

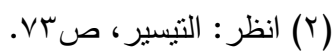

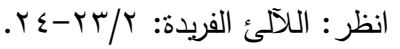

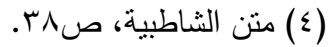

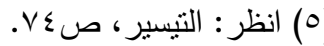

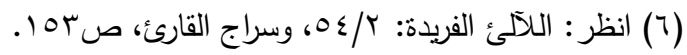

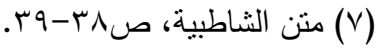




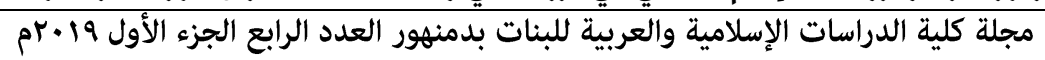

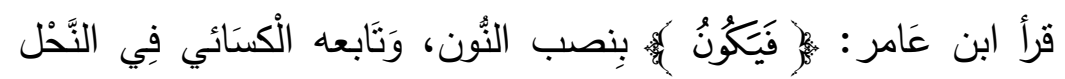

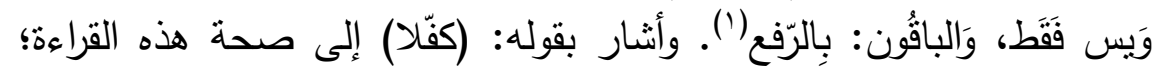

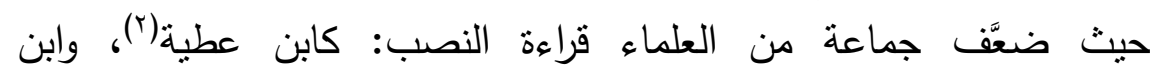
الجوزي(r)، والرازي(؟)، وغيرهم، ومعنى (كفّلا) أي: جعل كافلاً.

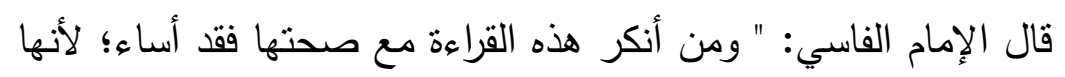

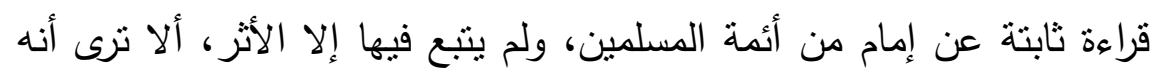

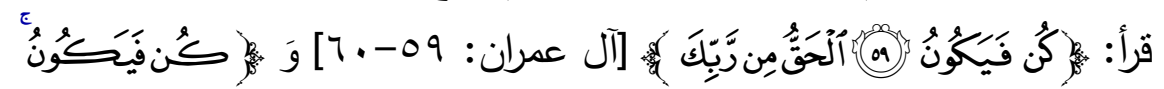

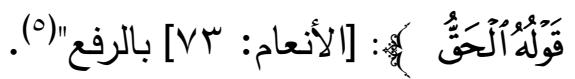
لذا نبه الإمام الثاطبي بقوله: (كفى راويا) على ظهوره، أب: كفى راويه إطالة القول وتكلف التأويل، وكفاه الوقيعة فيه من جهلة النحاة لظهور وجها ولها (وانقاد معناه): أي سهل ومشى معنى النصب مشبهاً يعملا، واليعمل: الجمل قول الإمام الشاطبي رحمه الله:

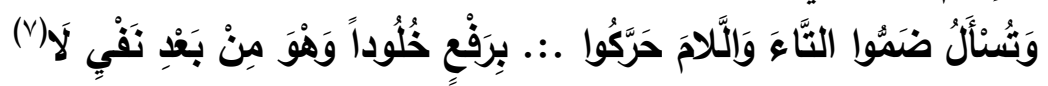

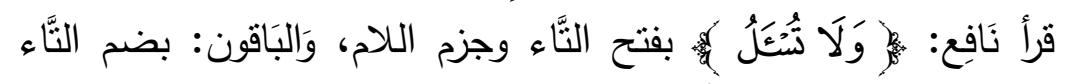

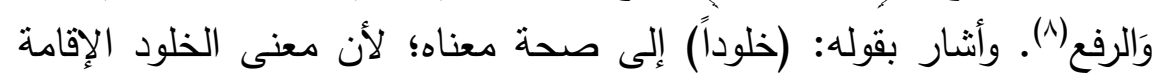

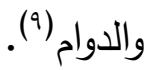

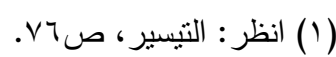

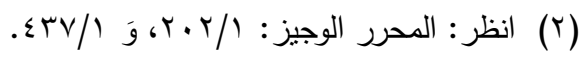

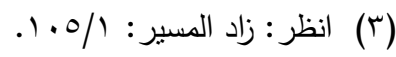

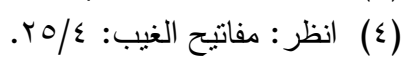

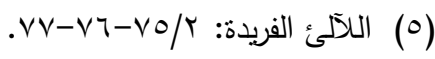

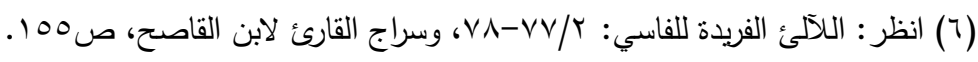

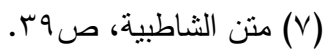

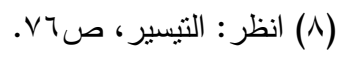

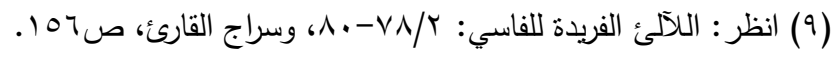




\section{رهوز القراء والرواة عند الإهام الشاطبي في درز الأهاني وأبعادها الدلالية فرش سورة البقرة نهوذجا}

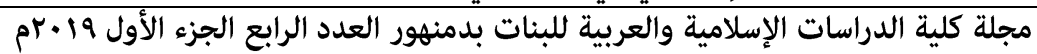

-الفرع السادس:

قول الإمام الشاطبي رحمه الله:

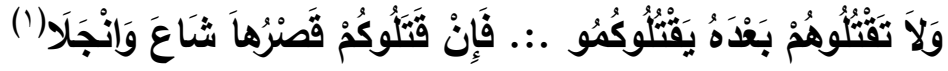

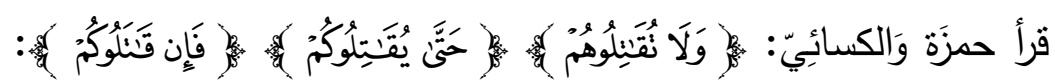

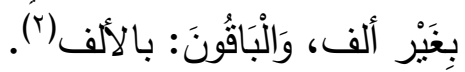

أثنى -رحمه الله- على قراعة القصر بقوله: (شاع وانجلا) أي: فثا

القصر واشتهر، وانكثف وظهر(r)، حيث رجح البعض عليها قراءة الإثبات،

كالإمام الطبري رحمه الله(ع). - الفرع السابع:

قول الإمام الشاطبي رحمه الله:

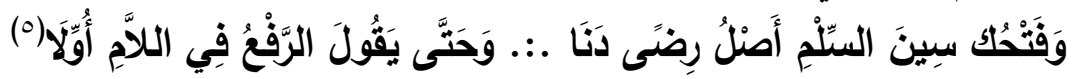

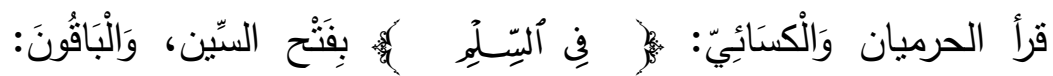

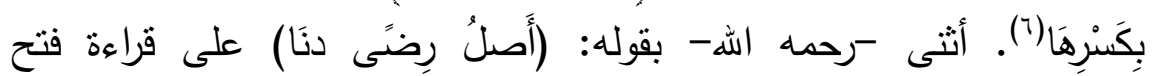
السين (V)؛ حيث رجح البعض القراءة بكسر السين، كالطبري(^)، ومكي بن أبي

طالب (9).

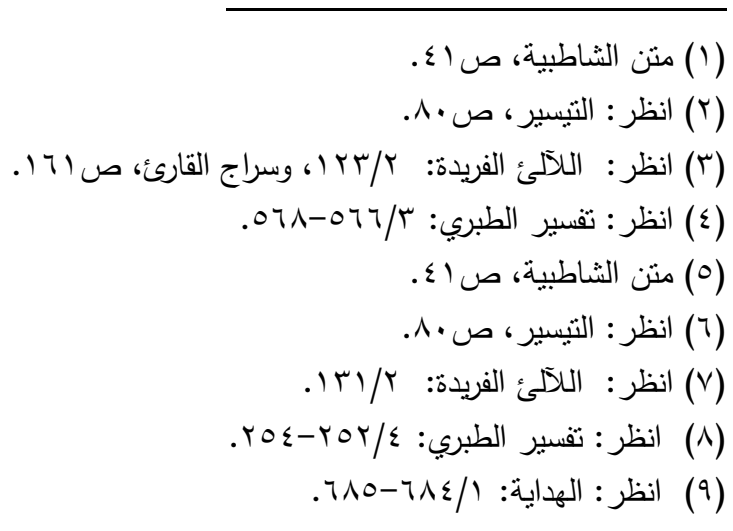


قول الإمام الشاطبي رحمه الله:

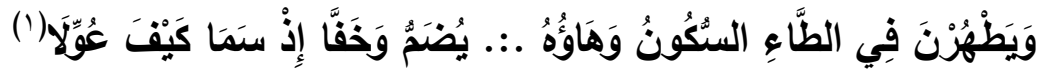

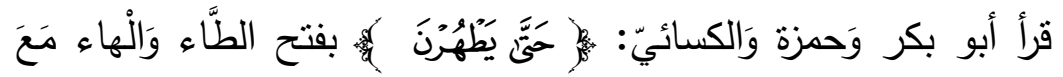

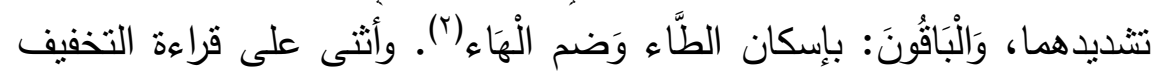
بقوله: (سما)، ونبه بقوله: (كيف عولا) على أن سبب السمو صحة استدلال الفريقين بـا(r)، حيث رجح البعض قراءة فتح الطاء والهاء مع تشديدهما، بهاء

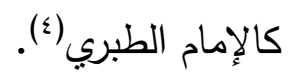
-الفرع التاسع: قول الإمام الشاطبي رحمه الله:

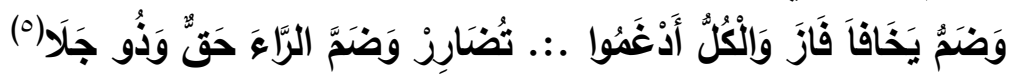

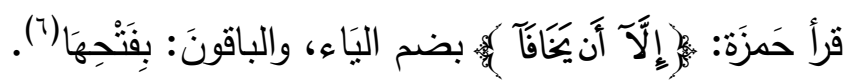
ضعَف بعض العلماء قراءة ضم الياء " بوجوه ضعيفة، منها: أنه بلزم من قرأ بالضم أن يقرأ: (فإن خيفا) وذلك غير لازم، ولو لزم للزم من قرأ بالفتح أن يقرأ (فإن خافا) وإنما هو في القراءتين من باب: الخروج من الغيبة إلى في الخطاب، وبسمى ذلك ونحوه (الالتفات) في علم البيان، وهو من محاسن الكلام. واختار أبو عبيد الضم، وصحح وجهه أبو علي. ولذلك أخبر الناظم

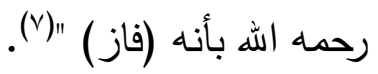

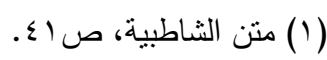

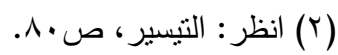

$$
\begin{aligned}
& \text { (ץ) انظر : اللَّلى الفريدة: }
\end{aligned}
$$

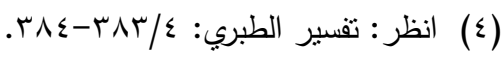

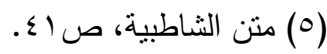

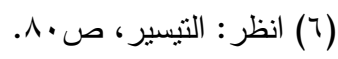

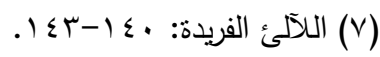


قول الإمام الثاطبي رحمه الله:

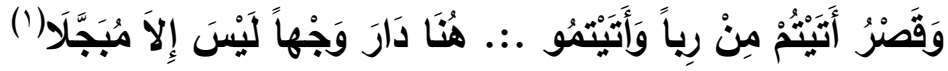

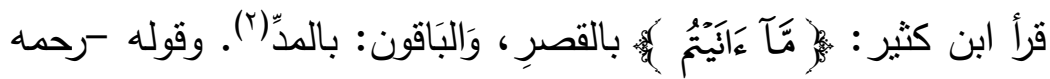

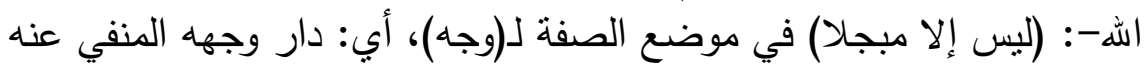

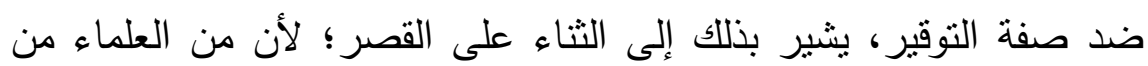

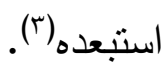
-الفرع الحادي عشر: قول الإمام الثاطبي رحمه الله:

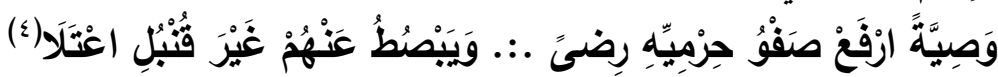

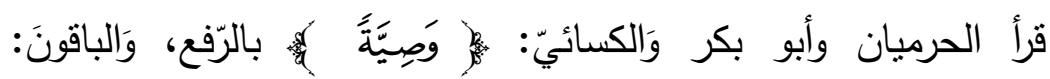

بالنصسب(0) أثنى على نقل من قرأ بالرفع بقوله: (صفو حرميه رضى) فأخبر أن صفوهم، أي: صافيهم، أي: نقلهم الصافي من كدر الطعن لصحته لصنه (رضى)

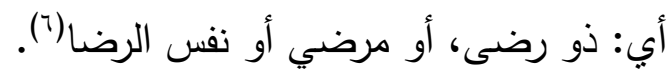

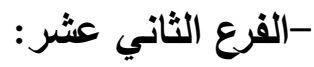
قول الإمام الشَاطبي رحمه الله:

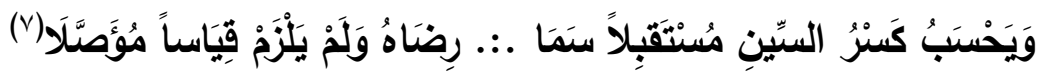

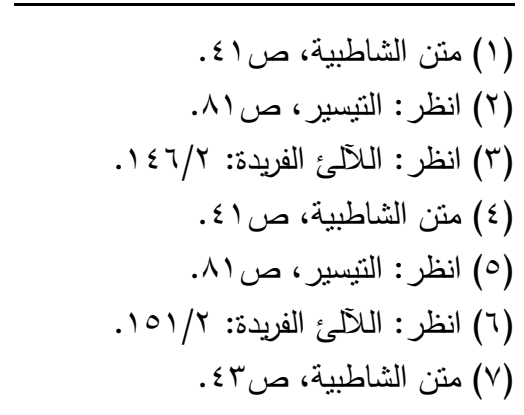




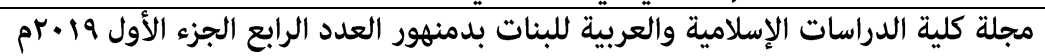

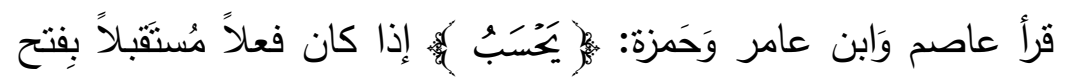

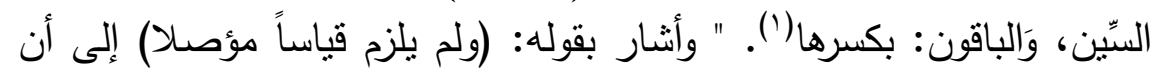

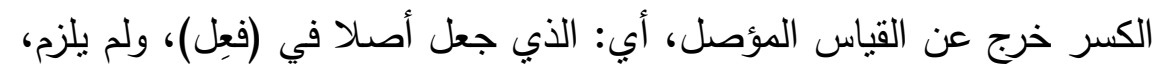
لأن القياس في (فعِل) أن يأتي مستقبله على (يفعَل)، نحو: علم بعلَم، ومرض جعَ يمرَض، وجنف يجنَف، إلا أنه قد صح عن العرب أنهم قالوا فيه: (بحسبب) بكسر السين، فلذلك قال: (سما رضاه) أي: علا الرضا به، وهو لغة أهل الحجاز، وروي أن النبي صلى الله عليه وسلم قرأ به، وقد جاء مثله في (نَعِم

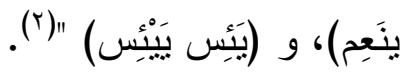

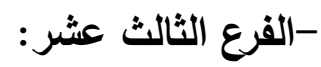
قول الإمام الشاطبي رحمه الله:

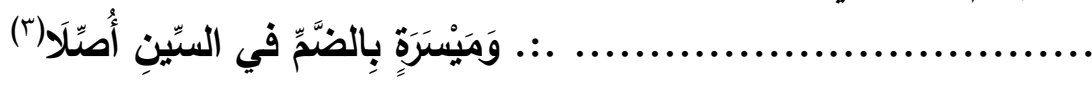

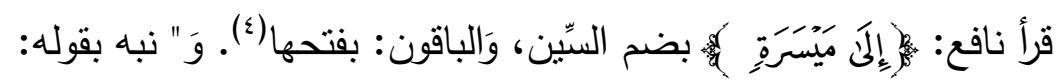

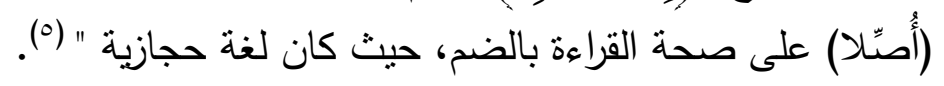

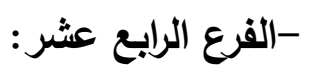
قول الإمام الشاطبي رحمه الله:

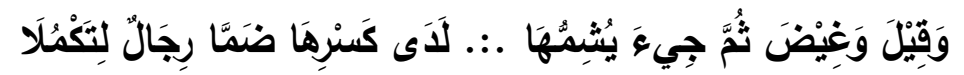

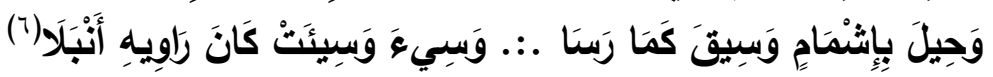

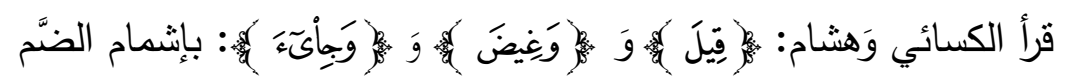
الأول حيثُ وقع، وَالباقون: بإخلاص كَسره، وقرأ ابن عَامر وَالكسائيّ:

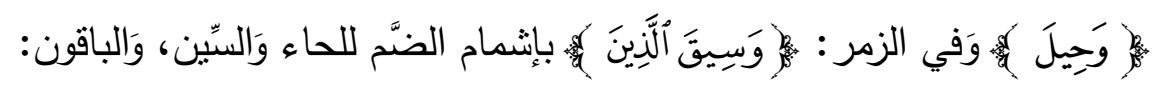

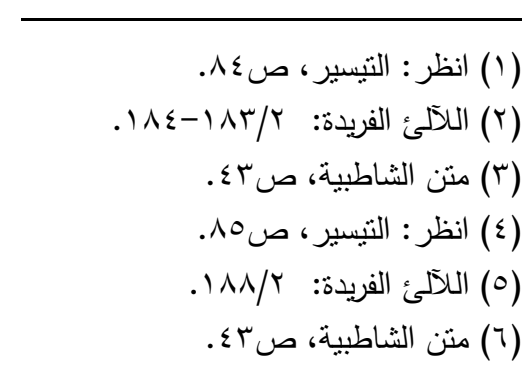




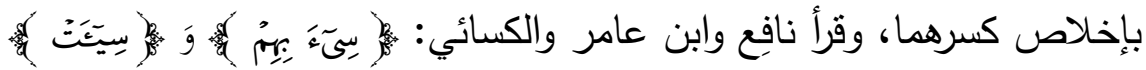
بإشمام السيّين الضَّم، في البقرة وَالعنكبوت وَالملك، وَالباقون: بإخلاص كسرة

أثناد -رحمه الله- بقوله: (رجال) بقراءة الإشمام، حيث وصف النقلة له بوصف زائد عن الذكورة وهو (الرجولة)، وفيه إنثارة إلى صحة القراءة بالإشمام، ولذلك عبر بقوله: (كما رسا)، ومعنى (رسا): ثبت واستقر، ومنه: جبال رواسي أي: ثوابت، والتقدير : إشماماً ثابتاً كثبات إثمام ما قبله، أي: أنها لغة ثابتة منقولة(r).

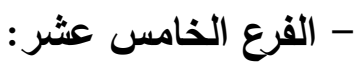
قول الإمام الشاطبي رحمه الله:

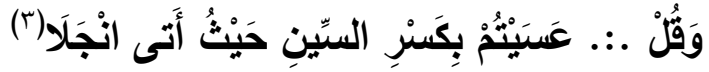

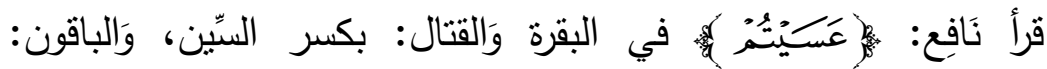
بفتحهاءً). وَنبّه -رحمه الله- بقوله (انجلا) إلى صحة القراءة بكسر السين، حيث رد هذه القراءة بعض العلماء، كالطبري(ه)، والزمخثري)(†)، وأبي

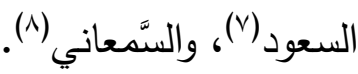


الإشارة إلى معنى من المعاني التي تناسب سياق الكلمة المقروءة،

$$
\text { وفيه فروع: الفرع الأول: }
$$

قول الإمام الشاطبي رحمه الله:

وفي الصابئين الهمز والصابؤون خذ .. وهزؤا وكفؤا في السواكن فصلا(ال)

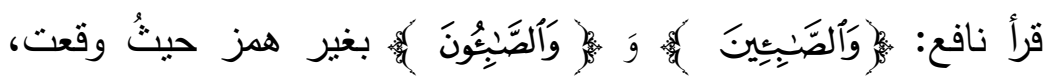

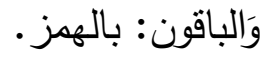

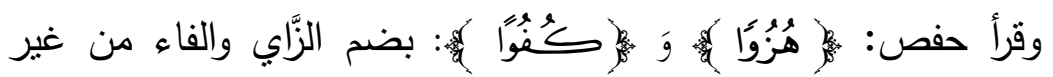
همز، وحمزة: بإسكان الزّاي وَالفاء وبالهمز فِي الوصل، وَالباقون: بالضّمّ والهمز (r).

عبّر -رحمه الله- بقوله: (خذ) فأمر بالأخذ بالهمز؛ لكونه الأصل على الاختيار (r)، ومعنى قوله: (في السواكن فصلا) أي: انتقلا في قراءته من نوع

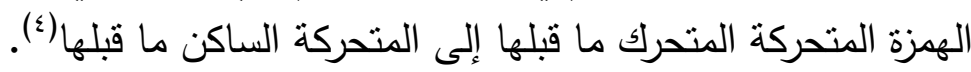

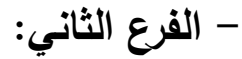
قول الإمام الشاطبي رحمه الله:

ويالغيب عما تعملون هنا دنا ... وغيتك في الثاني إلى صفوه دلاه(ه)

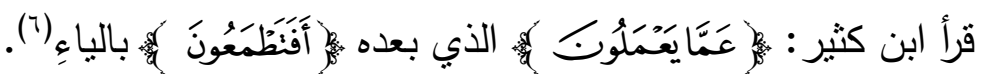
وَ " نبه بقوله (دنا) على دنوه مما انقضى الكلام فيه، أو على دنوه من الأفهام، لصحة معناه "(v)

$$
\begin{aligned}
& \text { (1) منن الثاطبية، صلr. }
\end{aligned}
$$

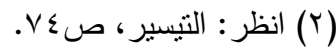

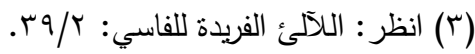

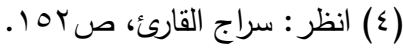

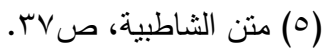

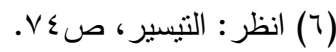

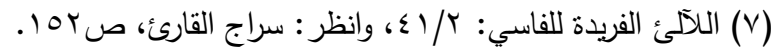


قول الإمام الشاطبي رحمه الله:

خطيئه التوحيد عن غير نافع .:. ولا يعبدون الغيب شايع دخلاد(1)

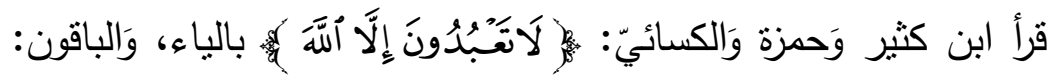

وعبّر -رحمه الله- بقوله: (شايع) أي: نابع الغيب هنا الغيب قبله؛ لأن

- معنى شايع: تابع، والدخلل: الذي بداخل المرء في أموره(r).

قول الإمام الشاطبي رحمه الله:

وقل حسناً شكراً وحسناً بضمه . ... وساكنه الباقون واحسن مقولاء(ء)

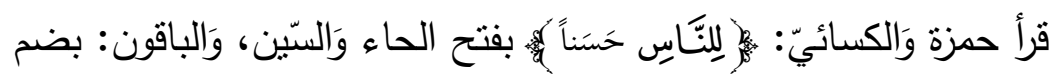
الحاء وإكان السيّن(0)، وعبر رحمه الله- بقوله: (شكراً) أي: " قل أيها الإنسان قولاً حسناً، أي: ما حسن من قولك في حال كونك شاكراً لله، أو لأجل

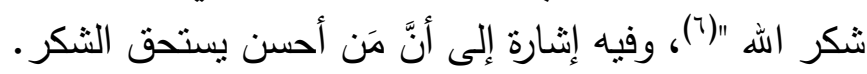

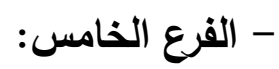

قول الإمام الشاطبي رحمه الله:

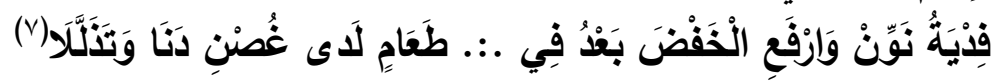

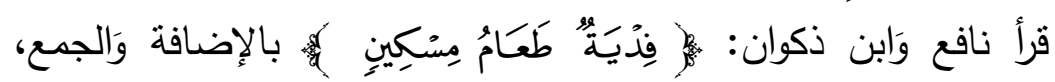

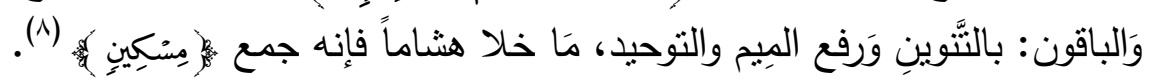

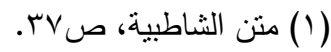

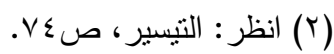

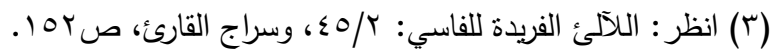

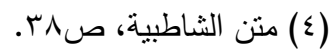

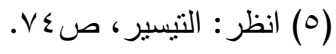

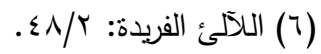

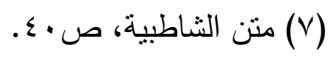

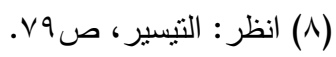




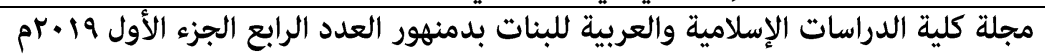
أشار -رحمه الله- بقوله: (لدى غصن دنا وتذللا) إلى قرب الإسلى معناه وسهولته، وأنه كالغصن الدالي المتذلل الذي بدرك ثرته كل واحد(')، فوجه القراءة بالتتوين والرفع: أن (الفدية) مبتدأ، وَ (طعام) بدل منها(؟).

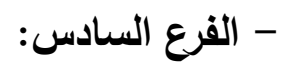
قول الإمام الشاطبي رحمه الله:

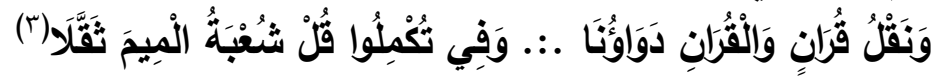

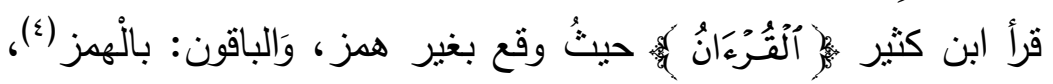
وأشار -رحمه الله- بقوله: (دواؤنا) إلى أنَّ نقل (القرآن) عن الأئمة وروايته: دواؤنا أيها القراء، وهو معنى حسن صحيح)(') وفيه إثارة أيضاً إلى التداوي بالقرآن الكريم.

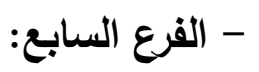
قول الإمام الشاطبي رحمه الله:

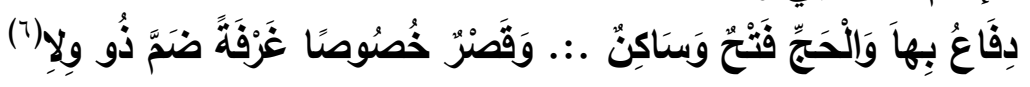

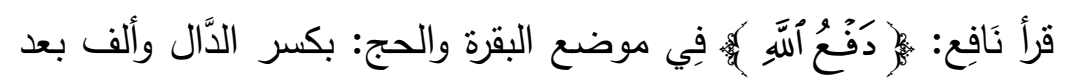

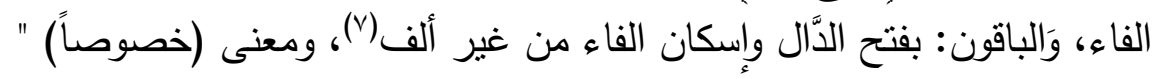
أي: خص السورتين المذكورتين بذلك خصوصاً "(^).

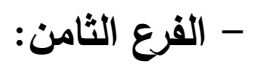
قول الإمام الشاطبي رحمه الله:

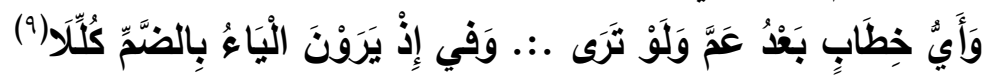

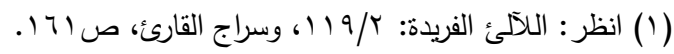

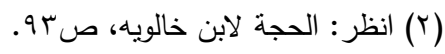

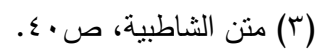

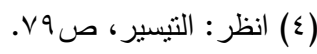

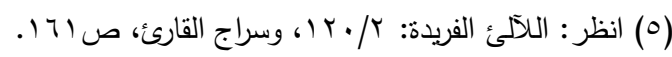

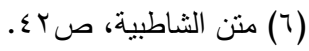

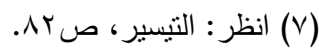

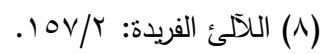

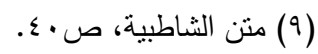




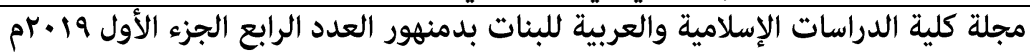

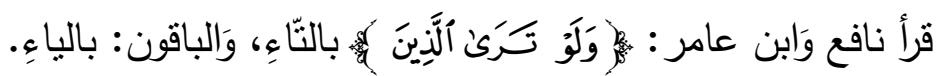

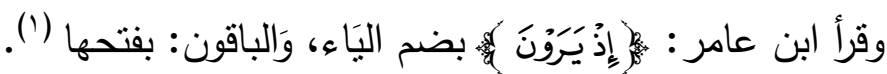
" وفي قوله (عم) إثنارة إلى أن الخطاب عاءٌ لكلّ من نتأتى منه

ومعنى (كُلِّل) أي: صورت الضمة على الياء فصارت كالإكليل عليها، أي: أن صورة الضمة عليها قد كللتها، أي: حفت بها، ومنه: روضة مكللة،

أي: محفوفة بالنور • والأكاليل أيضاً عصابة من الجوهر بلبسها الملوك(ب).

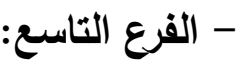
قول الإمام الشاطبي رحمه الله:

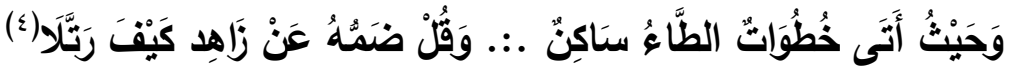

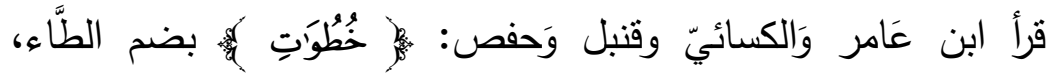
وَالباقون: بإسكانها(0)، وفي قول الناظل رحمه اله: (عن زاهد كيف رتلا) إثارة إلى أن الزهد وترثيل القرآن من أسباب العصدة من الشيطان.

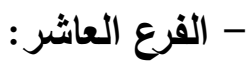
قول الإمام الشاطبي رحمه الله: يضاعفه ارفع في الحديد وههنا ... سما شكره والعين في الكل ثقلا كما دار (T)

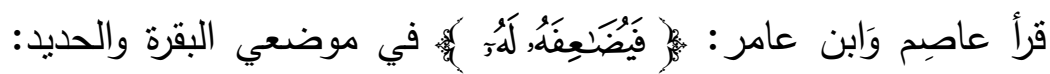
بنصب الفاء، وَالباقون: برفعها، وابن كثير وابن عامر : بتشديد العين من غير ألف، حيثُ وقع وَالباقون: بالألف مع التَّخفيف (1). 


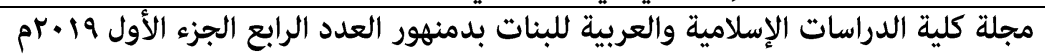

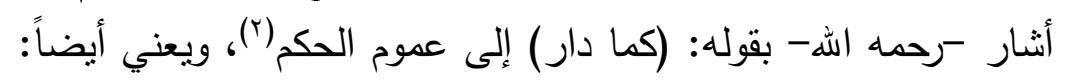

$$
\text { " في حال كونه دائراً، أي: متداولاً بين الرواة "("). }
$$

قول الإمام الشاطبي رحمه الله:

ودع ياء ميكائيل واللهز قبله ... على حجة والياء يحذف أجملاء)(

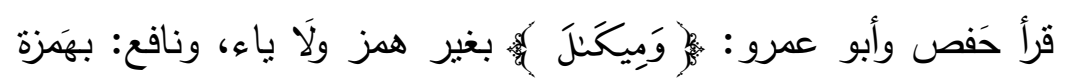

من غير ياء، والباقون: بياء بعد الْهزة(ه). "والحجة لحفص وأبي عمرو في قراءتهما إياه بغير همز ولا ياء: الإتيان به على أبنية العرب، لأنه ك(ميعاد ومبقات) صورة، وأن لغة أهل الحجاز كذلك... وإلى هذا أشنار بقوله (على

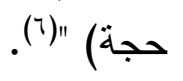

- الفرع الثاني عشر:

قول الإمام الثاطبي رحمه الله:

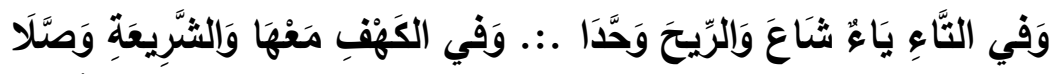

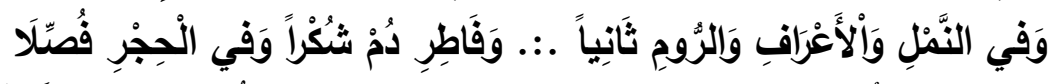

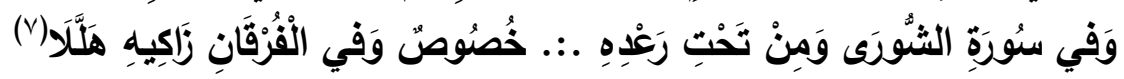

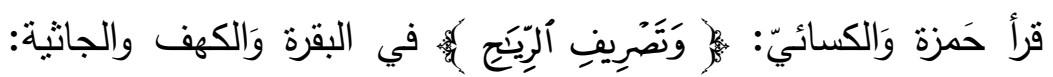

بالتَّححيد، وابن كثير وحمزة والكسائيّ في الأعراف والنمل والثّاني من الزّوم وفاطر : بالتّحيد، والباقون: بالجمع، وحمزة في الحجر بالتَّحيد، وابن كثير في 


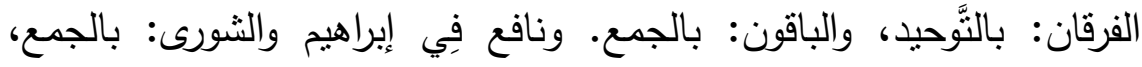

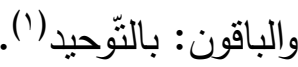

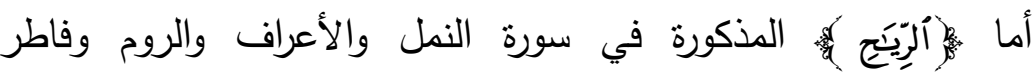
والفرقان: فإنه أربد بها الربح التي تتقدم المطر، وهي الجنوب؛ لأن العرب تقول: الجنوب تجمع السحاب، والثمال تعصره وتأتي بالمطر ... ولذلك عبر بقوله: (دم شكراً) أي: دم ذا شكر لله تعالى، وأتى بهذا المعنى بعد ذكر الريح الجالبة للمطر آمراً بدوام الشكر الله تعالى لذلك. وعبر بقوله (هلا) أي: قال: لا إله إلا الله، يعني: أنه ذكر الله عند النعمة الحاصلة بالغيب، ولم بذكر هذا المعنى فيما تقدم إلا في المواضع التي تجيء فيها الربح بالمطر ، ولم يذكر ذلك في غيرها(؟).

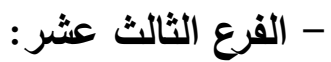
قول الإمام الثاطبي رحمه الله:

وحيث أتاك القدس إسكان داله ... دواء وللباقين بالضم أرسلا(ז)

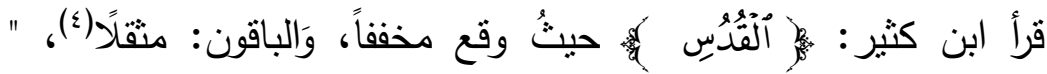
والحجة لمن قرأ بالإسكان، أنه استتل اجتماع ضمتين فخفف بتسكين إحداهما، وإليه أثار بقوله: (دواء) يعني: أنه دواء من الثقل "(ه). 


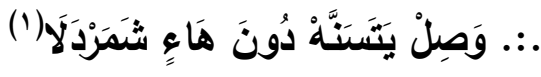

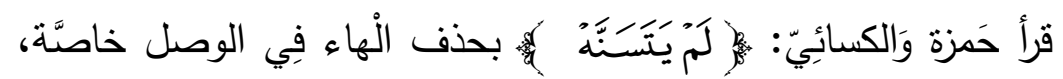

وَالباقون: بإثباتها في الحالين (r).

وأثنار بقوله: (شمردلا) إلى خفة القراءة بحذف الهاء؛ لأن معنى

$$
\begin{aligned}
& \text { الثمردل: الخفيف(r). } \\
& \text { * المطاب الثالث: } \\
& \text { الإشارة إلى توجيه القراءة، وفيه فروع: } \\
& \text { - الفرع الأول: }
\end{aligned}
$$

وقيل وغيض ثم جيء يشمها ... لاى كسرها ضماً رجال لتكملا(ء)

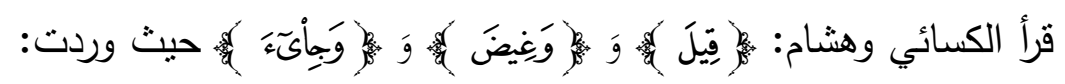

بإثمام الضَّم الأول(0)، ووجه القراءة بالإشمام: الدلالة على الأصل، وأن الكلمة

تصير كأنها منطوق بها على أصلها من غير تغيير، وإلى ذلك أشنار بقوله: (لتكملا) أي: لتكمل الدلالة على الأمرين، لأن من شأن العرب في كثير من فئ فئ كلامها المحافظة على بقاء ما بدل على الأصول(؟)، فالإشمام فيه من الكمال ما ليس في الكسر الخالص؛ وهو الإشارة لأصل الكلمة كما تقدم، فتكمل الكلمة بالإشارة لأصلها الحقيقي.

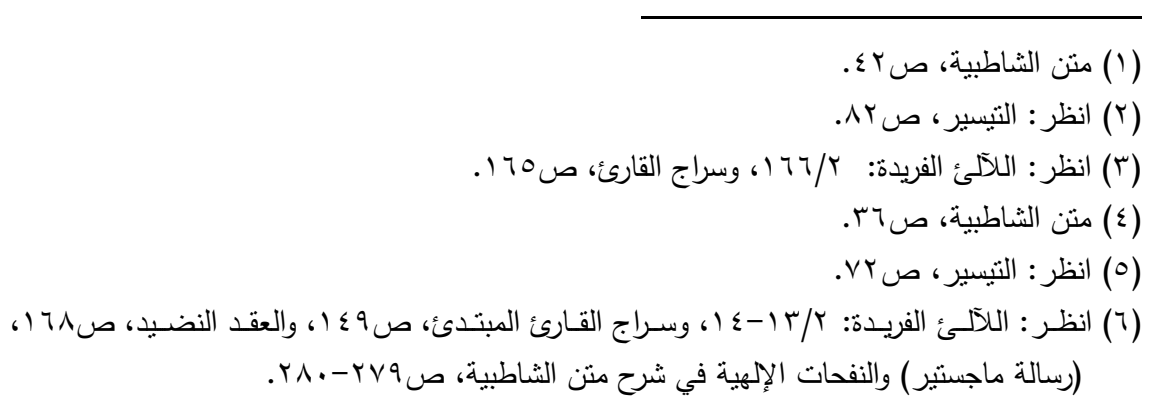




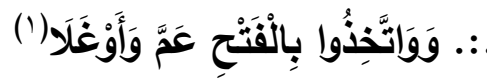

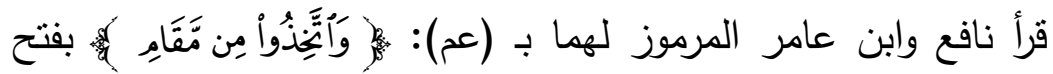

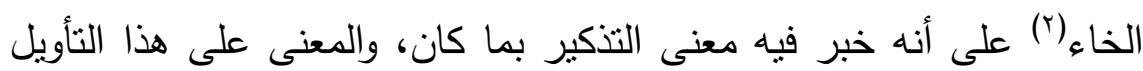

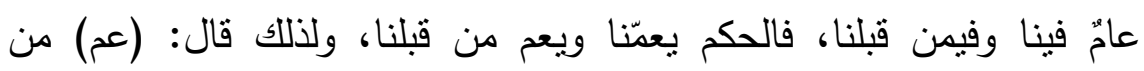
العموم، وَ (أوغلا) يقال: أوغل في الثيء إذا أمعن فيه، ومنه: الإيغال في ولي

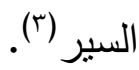
- الفرع الثالث: قول الإمام الشاطبي رحمه الله:

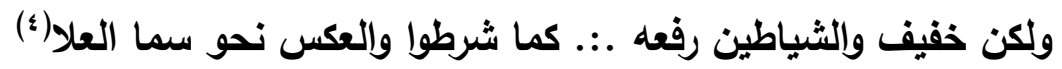
قرأ ابن عامر وحَمزة والكسائيّ:

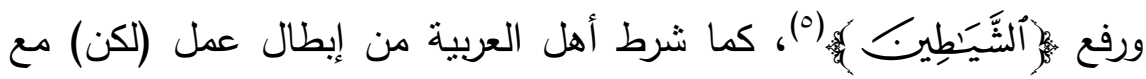
التخفيف، وإلى ذلك أثنار بقوله: (كما شرطوا)(`آ.

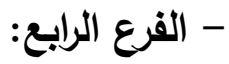
قول الإمام الشاطبي رحمه الله:

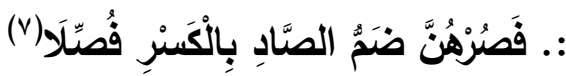

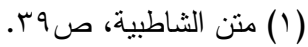

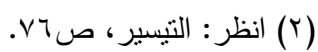

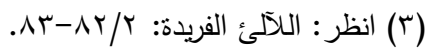

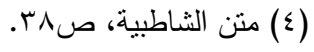

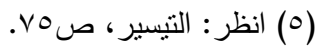

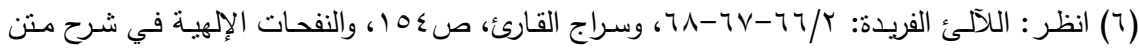

$$
\begin{aligned}
& \text { الثناطبية، ص الوجن. }
\end{aligned}
$$

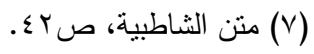




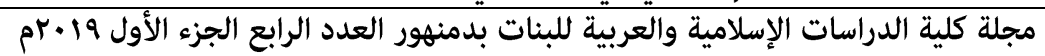

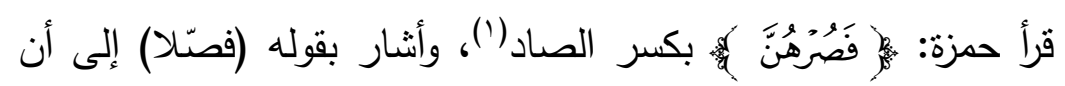

معنى الكسر: فصيّل بمعنى الضم، أي: بُيّن بمعنى الضم؛ لأن كل واحد منهما

يوضح معنى الآخر حيث كانا بمعنى واحد(r).

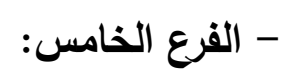

قول الإمام الشاطبي رحمه الله:

وفيها وفي الأعراف نغفر بنونها ... ولا ضم واكسر فاعه حين ظلا

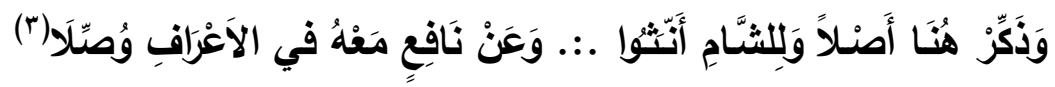

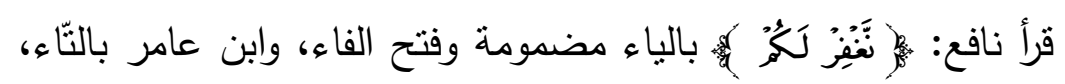

والباقون: بالنّون مفتوحة وَكسر الفاء(ء).

ووجه القراءة بالياء على التذكير : أنه الأصل، وإلى ذلك أشار بقوله:

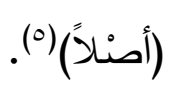

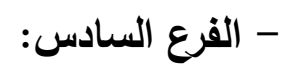

قول الإمام الشاطبي رحمه الله:

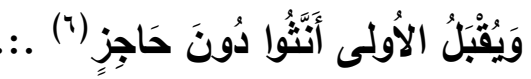

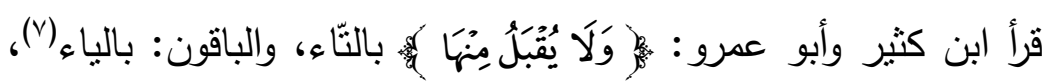

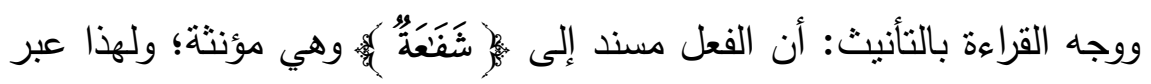

بقوله: (دون حاجز) أي: دون مانع من التأنيث(^).

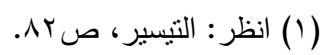

$$
\begin{aligned}
& \text { (Y) انظر : اللآلى الفريدة: }
\end{aligned}
$$

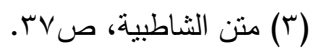

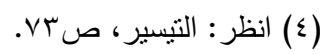

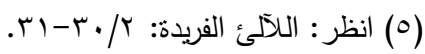

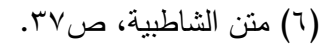

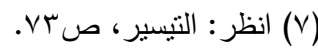

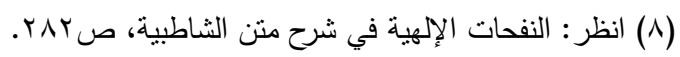


رموز القراء والرواة عند الإهام الثاطبي في حرز الأهاني وأبعادها الدلالية فرش سورة البقرة نهوذجا

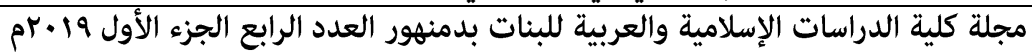

- الفرع السابع: -

قول الإمام الشاطبي رحمه الله:

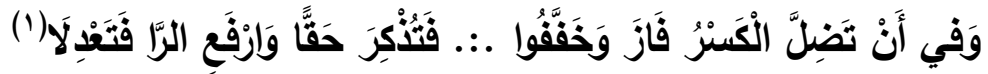

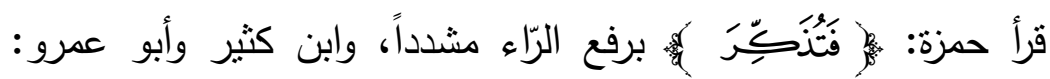

بنصبها مخففاً، والباقون: بالنّصب مع التّنديد(؟). وعبّر رحمه الله- بقوله:

(فتعدلا)؛ لأنه لا بستقيم مع كسر الهمزة ووجود الفاء إلا الرفع(r).

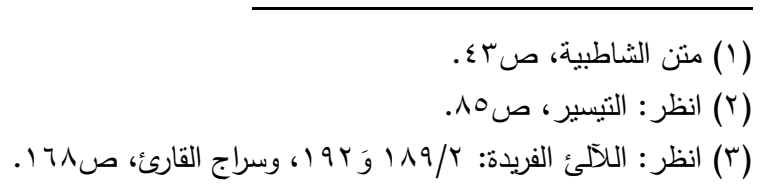




\section{الخاتمة}

الحمد لله الذي وفق لإتمام هذا البحث، وصلاةً وسلاماً على المبلّغ عن

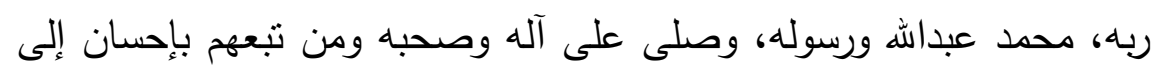

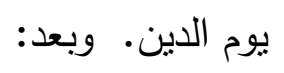

فمن أهم النتائج التي توصلت إليها من خلال هذا البحث:

1- القيمة العلمية لمنظومة الثاطبية، واهتمام العلماء بها من حيث شرح

أبياتها، وكثف أسرارها، وحل رموزها، وانكباب القراء عليها حفظاً وشرحاً

$$
\text { ومدارسة. }
$$

r- منهج الإمام الثاطبي في المعاني البديعة للرموز، والإشارات البلاغية،

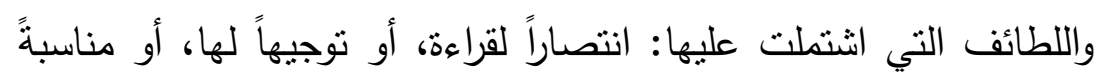

$$
\text { لسياق. }
$$

r- احتواء الثاطبية على الكثير من الدرر التي لم يتم اكتشافها.

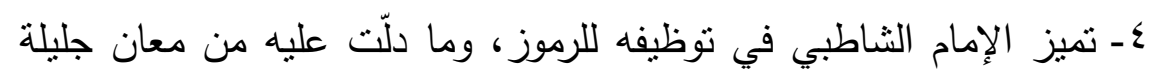
بليغة. وصلى الله وسلم على نبينا محمد وعلى آله وصحبه أجمعين. 
رموز القراء والرواة عند الإهام الثاطبي في درز الأهاني وأبعادها الدلالية فرش سورة البقرة نهوذجا

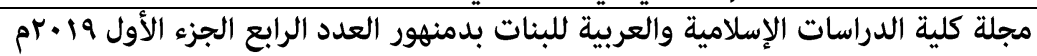

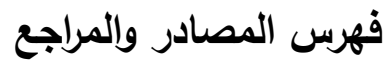

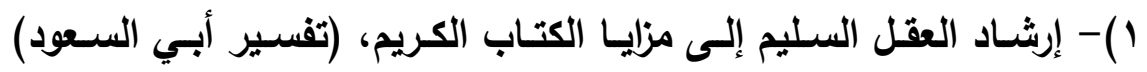

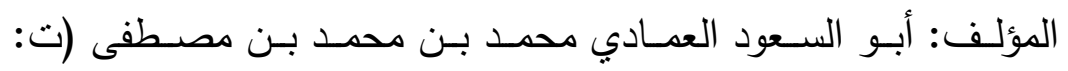

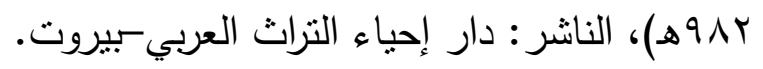

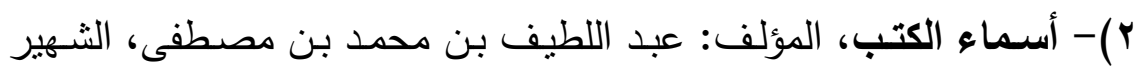

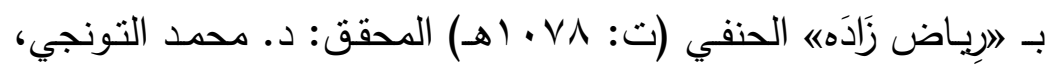

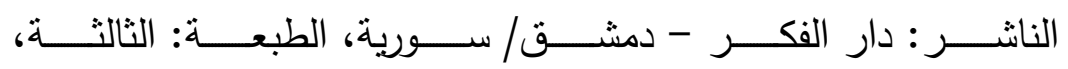

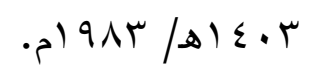

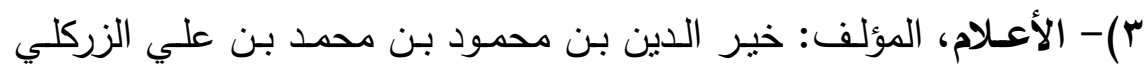

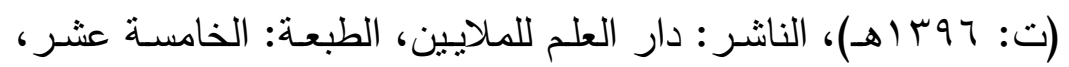

$$
\text { . }
$$

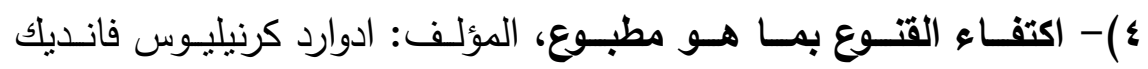

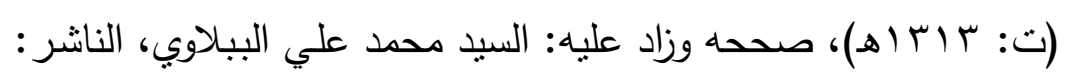

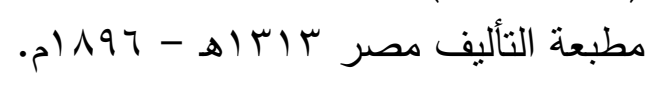

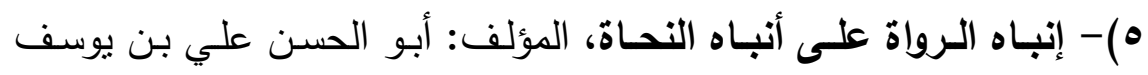

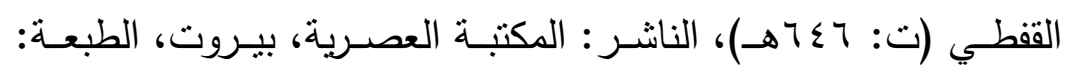

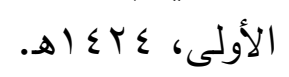

7)- إيضاح المكنون في الذيل على كشف الظنون، المؤلف: إسماعيل بن

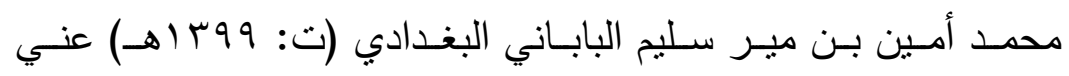

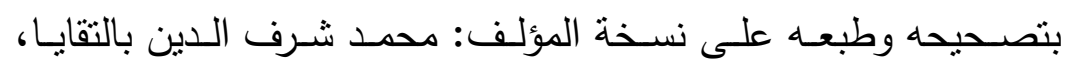

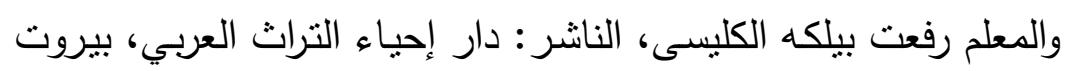

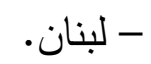

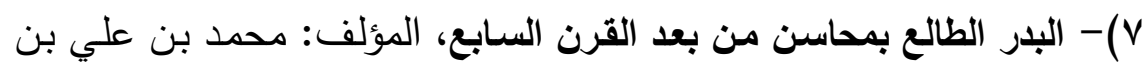

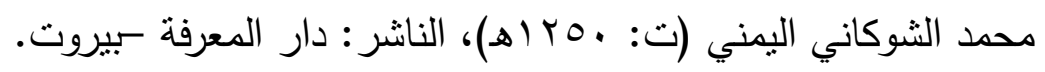




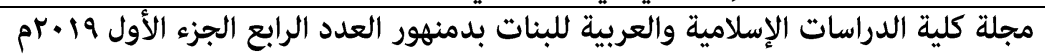

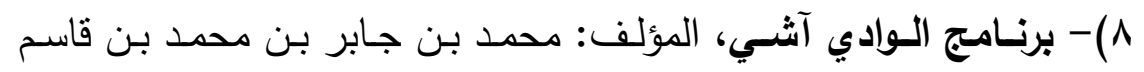

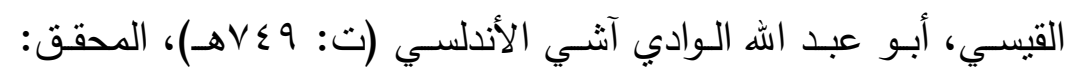

محمد محفوظ، الناشر: دار المغرب الإسلامي - أثنيا- بيروث، الطبعة:

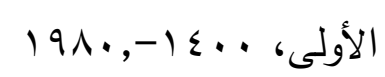

9)- بغية الوعاة في طبقات اللغويين والنحاة، المؤلف: عبد الرحمن بن أبي بكر، جلال الدين السيوطي (ت: 1 (19ه)، المحقق: محمد أبو الفضل فئل

$$
\text { إبراهيم، الناشر : المكتبة العصرية - لبنان، صيدا. }
$$

• 1) - تاج العروس من جواهر القاموس، المؤلف: محمّد بن محمّد بن عبد

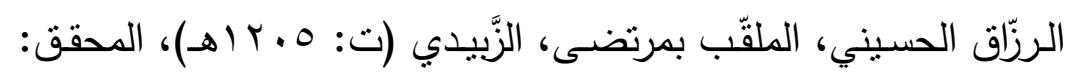
مجموعة من المحققين، الناشر : دار الهداية. (1) - تاريخ الإسـلام ووفيات المشاهير والأعـلام، المؤلف: محمد بن أحمد

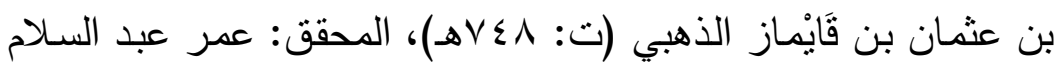
التذمري، الناشر : دار الكتاب العربي، بيروت.

r 1 ) - تعـديلات بعض شـراح الثـاطبية وتقيـــاتهم فـي أبياتهـا، للدكتور عبدالقيوم السندي، بحث مستل من مجلـة البحوث والدراسـات القرآنيـة-

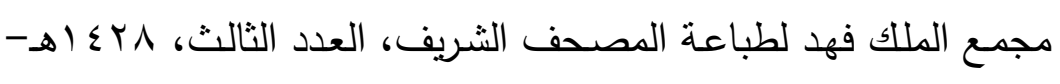

$$
\cdot{ }^{3} \cdot \mathrm{v}
$$

ب 1) - تفسير القرآن، المؤلف: منصور بن محمد بن عبد الجبار السمعاني التميمي (ت: 9 ـ §ه)، المحقق: باسر بن إبراهيم، وغنيم بن عباس بن

$$
\text { غنيم، الناشر : دار الوطن، الرياض - السعودية. }
$$

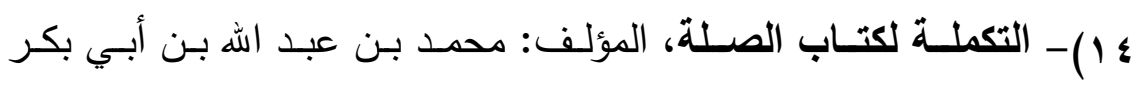

القضـاعي البلنسـي، ابـن الأبـار (ت: 1017هـ)، المحقـق: عبـد السـلام

$$
\text { الهراس، الناشر : دار الفكر للطباعة - لبنان } 0 \text { 1ـ اهـ الهـ } 990 \text { ام. }
$$

ه ) - التيسيز في القراءات السبع، المؤلف: عثمان بن سعيد بن عثمان أبو عمرو الداني (ت: عـ عهـ)، المحقق: أوتو تربزل، الناشر : دار الكتاب

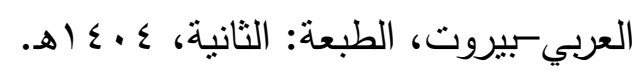


رموز القراء والرواة عند الإهام الثاطبي في درز الأهاني وأبعادها الدلالية فرش سورة البقرة نهوذجا

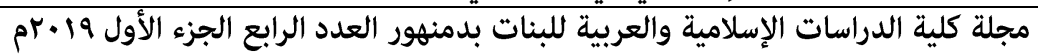

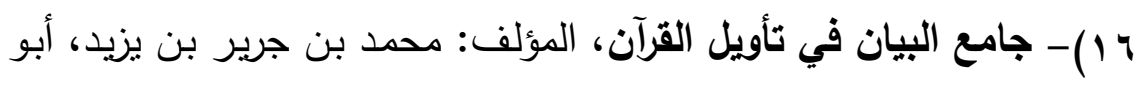
جعفر الطبـري (ت: • اسهـ)، المحقـق: أحمـد محمـد شـاكر، الناشـر :

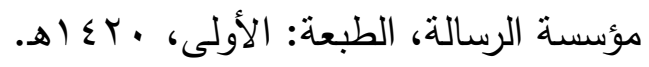

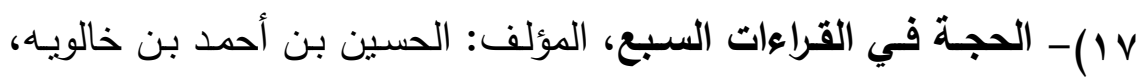
(ت: • • هـه)، المحقق: د. عبد العال سالم مكرم، الناشر : دار الثروق

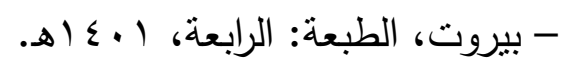
1 1) - حرز الأمـاني ووجـه التهاني في القراءات السبع، (متن الثـاطبية)، المؤلف: القاسـم بـن فيـره بـن خلف الثـاطبي (ت: . 90هـ)، المحقق: محمد تميم الزعبي، الناشر : مكتبة دار الهدى، ودار الغوثاني للارراسات

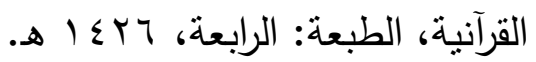
9 1 ) - الدرر الكامنة في أعيان المائة الثامنـة، المؤلف: أحمد بن علي بن محمد بن حجر العسقلاني (ت: بهـهـ)، المحقق: محمد عبد المعيد

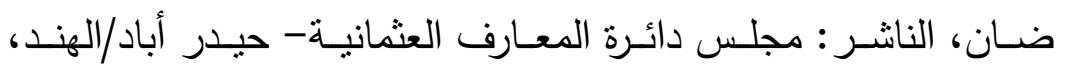

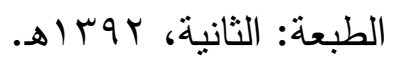

• ب) زاد المسير في علم التفسير، المؤلف: عبد الرحمن بن علي بن محمد الجـوزي (ت: Yو

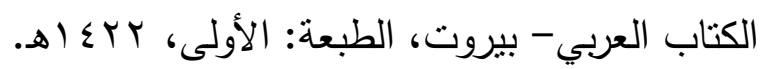

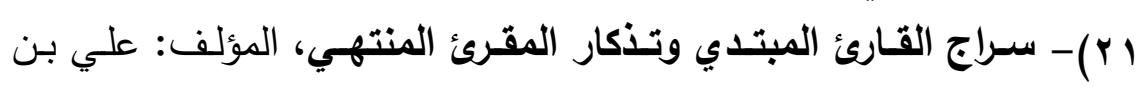

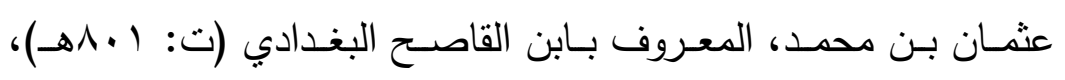

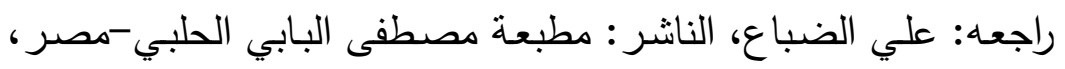

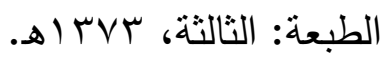
r r - سمط النجوم العوالي في أنباء الأوائل والتوالي، المؤلف: عبد الملك بن حسين بن عبد الملك العصامي المكي (ت: 111 (اهـ)، المحقق: عادل أحمد عبد الموجود- علي محمد معوض، الناشر : دار الكتب العلمية -

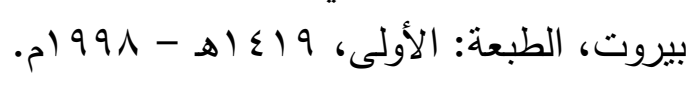

ب ץ) - سـير أعـلام النبلاء، المؤلف: محمد بن أحمد بن عثمـان بن قَايْمـاز 


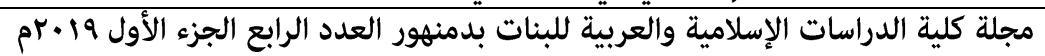

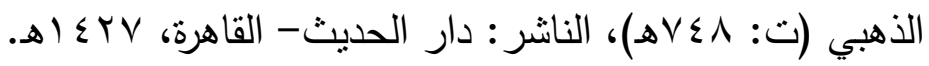

ع r) - شذرات الذهب في أخبار من ذهب، المؤلف: عبد الحي بن أحمد ابن

العماد الحنبلي، (ت: 9 ( • (هـ)، حققه: محمود الأرناؤوط، الناشر : دار

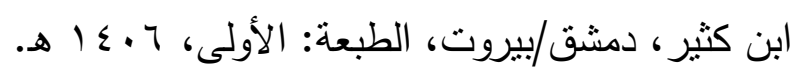

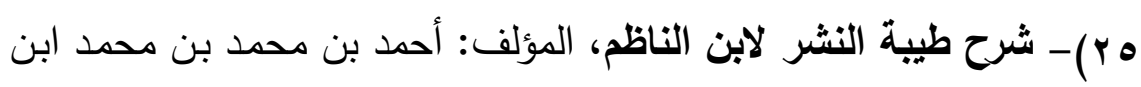

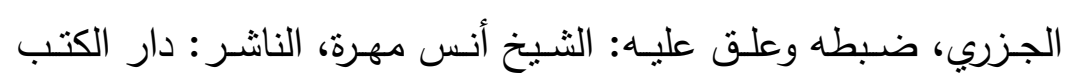

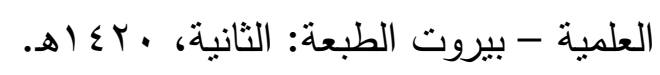

צ ץ) - الضوء اللامع لأهل القرن التاسع، المؤلف: محمد بن عبد الرحمن بن محمد السـخاوي (ت: r · وهـ)، الناشـر : منشـورات دار مكتبـة الحيـاة-

$$
\text { بيروت. مبرت }
$$

(rV السيوطي (المتوفى: الوا9ه)، الناشـر: دار الكتب العلمبـة - بيـروت،

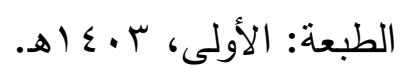

^r ) - طبقات الشافعية الكبرى، المؤلف: تاج الدين عبد الوهاب بن تقي الدين السبكي (المتوفى: المه)،المحقق: د. محمود محمد الطناحي د.. عبد

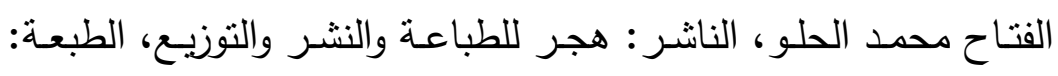

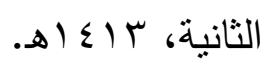

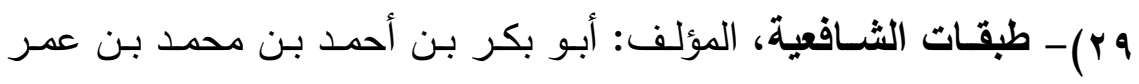
الأسـدي الثــبي الدمثـقي، تقي الـدين ابـن قاضــي شـهبة (المتـوفى:

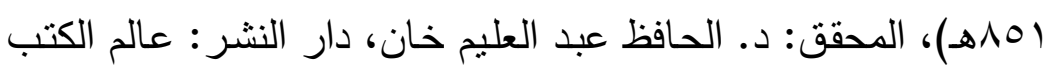

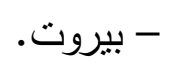

• ب) العنايـة بـالقرآن الكريم وعلومـه من بدايـة القرن الرابـع الهجري إلى .

عصـرنا الحاضـر، المؤلف: د. نبيـل بن محمـ آل إســاعيل، الناشـر :

مجمع الملك فهد لطباعة المصحف الثربف بالمدينة المنورة.

(ب)- العقد النضيد في شرح القصيد، المؤلف: أحمد بن يوسف بن محمد،

المشـهور بـ (السـين الحلبي)، (ت: 707 هـ)، وهـي رسـالة لنيـل درجـة 
رهوز القراء والرواة عند الإمام الشاطبي في درز الأماني وأبعادها الدلالية فرش سورة البقرة نهوذجا

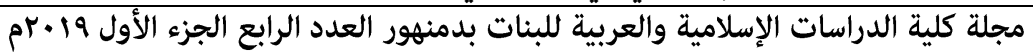

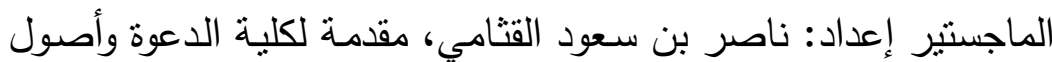

$$
\text { الدين، بجامعة أم القرى. }
$$

r r)- غاية التهاية في طبقات القراء، المؤلف: ابن الجزري، محمد بن محمد

بن يوسف، (ت: سمريه)، الناشر : مكتبة ابن تيمية.

بr)- فوات الوفيات، المؤلف: محمد بن شـاكر بن أحمد، الملقب بصـلاح

الدين (ت: ع צاهـ)، المحقـق: إحسـان عبـاس، الناشـر : دار صـادر -

$$
\text { بيروث. }
$$

ع ب) - قراءة الامام نافع عند المغاريـة من روايـة أبي سعيد ورش، المؤلف:

د. عبـدالهادي حميتـو، الناشـر : وزارة الأوقـاف والثــؤون الإســلامية-

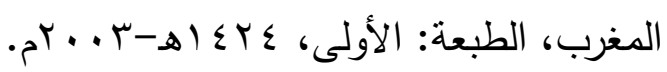

هب)- الكثـاف عـن حقـائق غـوامض التتزيـل، المؤلف: محمـود بـن عمر الزمخري (ت: مبههـ)، الناشر: دار الكتاب العربي-بيروت، الطبعة:

\section{الثالثة، V • ع اهـ.}

צr) - كثف الظتون عن أسامي الكتب والفتون، المؤلف: مصطفى بن عبد الله كاتب جلبي القسطنطيني المشهور باسم حاجي خليفة أو الحاج خليفة

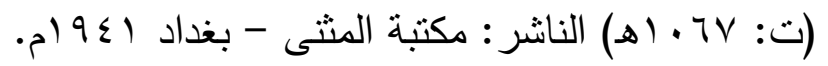

V - اللَّئ القريدة في شرح القصيدة، المؤلف: محمد بن الحسن بن محمد الفاسي، (ت: 707 7هـ)، المحقق: عبدالرازق علي موسى، الناشر : مكتبة

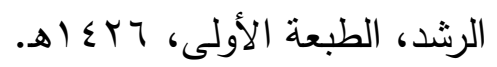

مس - المحر الوجيز في تفسير الكتاب العزيز، المؤلف: عبد الحق بن غالب بن

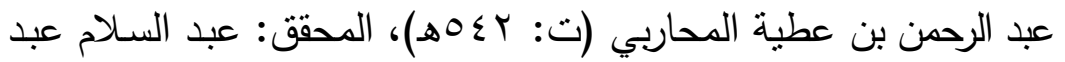
الثـافي محمد، الناشـر : دار الكتب العلمية-ـبيروت، الطبعـة: الأولى، هـ 1 ا ه

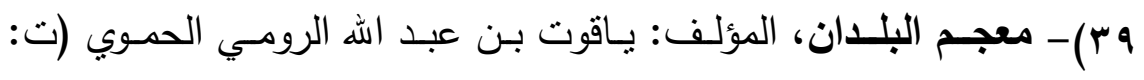
جr 7ه)، الناشر: دار صادر ، بيروت، الطبعة: الثانية، 990 (م. 
رهوز القراء والرواة عند الإهام الثاطبي في درز الأماني وأبعادها الدلالية فرش سورة البقرة نهوذجا

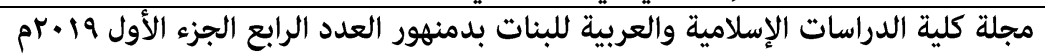

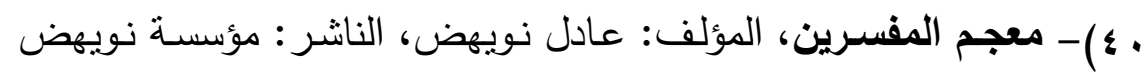

الثقافية للتأليف والترجمة والنشر ، الطبعة: الثالثة، 9 ـ ـ اهـ.

(§)- معرفة القراء الكبار على الطبقات والأعصار ، المؤلف: محمد بن أحمد

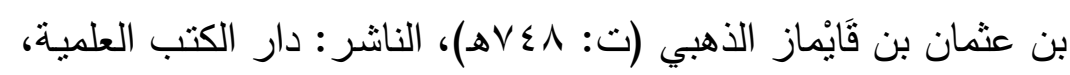

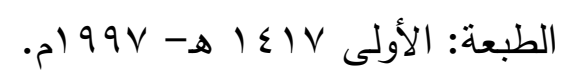

ץ \& ) مفاتيح الغيب = التفسير (لكبير، المؤلف: محمد بن عمر بن الحسن الرازي (ت: 7 • 7هـ)، الناثـر : دار إحيـاء التـراث العربـي- بيـروت، الطبعـة:

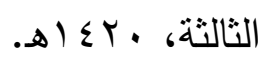

بع)- النفحات الإلهية في شرح متن الثاطبية، المؤلف: محمد عبد الدايم خميس، الناشر: دار المنار للنشر •

ع )- نفح الطيب من غصن الأندلس الرطيب، وذكر وزيرها لسان الدين بن

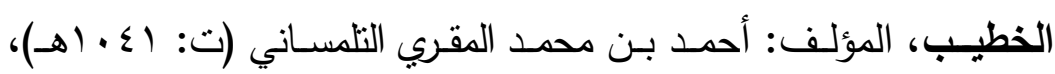
المحقق: إحسان عباس، الناشر: دار صاد، بيروت.

ء) - الهدايـة إلى بلـوغ النهايـة في علم معاني القرآن وتفسيره، وأحكامسه، وجمل من فنون علومه، المؤلف : مكي بن أبي طالب حَمّوش القبسي

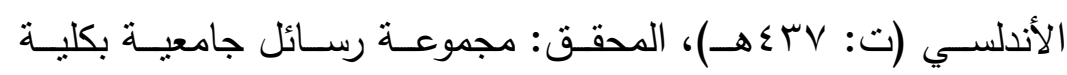
الدراسـات العليا والبحثث العلمي، جامعة الثـارقة، بإثـراف أ.د : الثـاهد البوشـيخي، الناشـر : مجموعـة بحـوث الكتـاب والسـنة - كلبـة الثــربعة

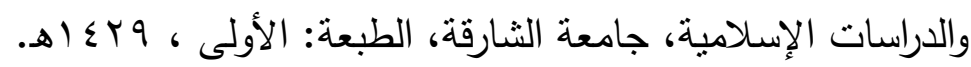
ج ء) - الوافي في شرح الشاطبية في القراعات السبع، المؤلف: عبد الفتاح بن عبد الغنـي بـن محمد القاضـي (ت: ب .ع اهـ) الناشـر : مكتبـة السـوادي

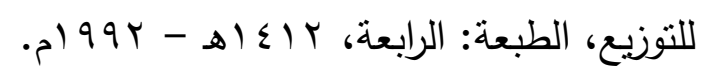

\& V إبراهيم بن أبي بكر ابن خلكان البرمكي (ت: الهـهـ)، المحقق: إحسان

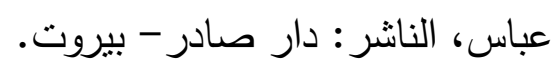




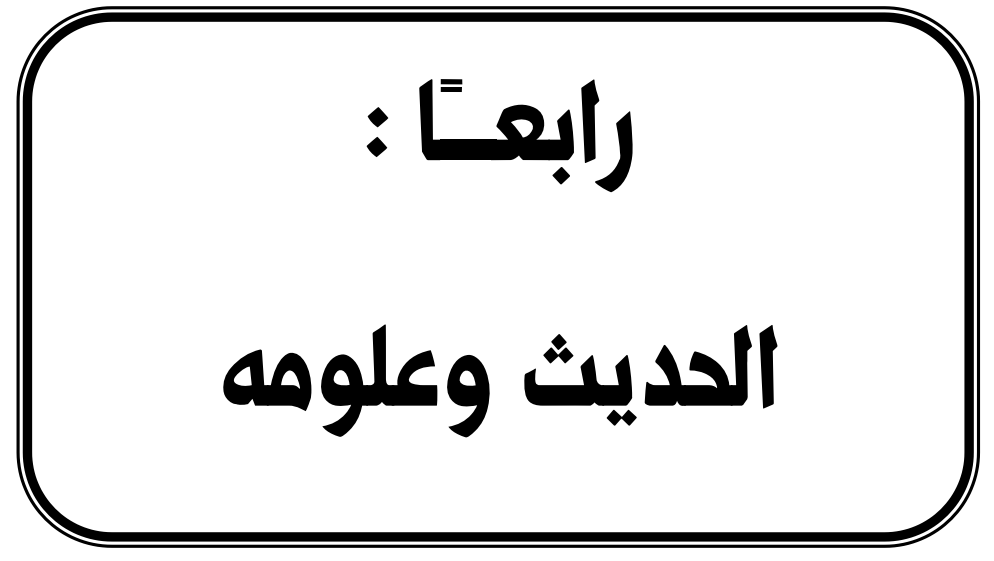


